Exon capture optimization in a large-genome amphibian

\title{
1 Exon capture optimization in large-genome amphibians
}

2

3

4

8 Evan McCartney-Melstad ${ }^{1 \S}$, Genevieve G. Mount ${ }^{2}$, H. Bradley Shaffer ${ }^{1}$

9

$10{ }^{1}$ Department of Ecology and Evolutionary Biology, La Kretz Center for California

11 Conservation Science, and Institute of the Environment and Sustainability, University of

12 California, Los Angeles, California 90095, USA

$13{ }^{2}$ Department of Biological Sciences, Museum of Natural Science, Louisiana State University,

14 Baton Rouge, LA 70803, USA

15

$16{ }^{\S}$ Corresponding author

17

18 Email addresses:

19 EMM: evanmelstad@ucla.edu

20 GGM: gmount1@1su.edu

$21 \quad$ HBS: brad.shaffer@ucla.edu 
bioRxiv preprint doi: https://doi.org/10.1101/021253; this version posted June 19, 2015. The copyright holder for this preprint (which was

not certified by peer review) is the author/funder, who has granted bioRxiv a license to display the preprint in perpetuity. It is made available under aCC-BY-NC-ND 4.0 International license.

Exon capture optimization in a large-genome amphibian

\section{Abstract}

Background

Gathering genomic-scale data efficiently is challenging for non-model species with large, complex genomes. Transcriptome sequencing is accessible for even large-genome organisms, and sequence capture probes can be designed from such mRNA sequences to enrich and sequence exonic regions. Maximizing enrichment efficiency is important to reduce sequencing costs, but, relatively little data exist for exon capture experiments in large-genome non-model organisms. Here, we conducted a replicated factorial experiment to explore the effects of several modifications to standard protocols that might increase sequence capture efficiency for large-genome amphibians.

\section{Methods}

We enriched 53 genomic libraries from salamanders for a custom set of 8,706 exons under differing conditions. Libraries were prepared using pools of DNA from 3 different salamanders with approximately 30 gigabase genomes: California tiger salamander (Ambystoma californiense), barred tiger salamander (Ambystoma mavortium), and an F1 hybrid between the two. We enriched libraries using different amounts of $\mathrm{c}_{0} \mathrm{t}-1$ blocker, individual input DNA, and total reaction DNA. Enriched libraries were sequenced with 150 bp paired-end reads on an Illumina HiSeq 2500, and the efficiency of target enrichment was quantified using unique read mapping rates and average depth across targets. The different enrichment treatments were evaluated to determine if $\mathrm{c}_{0} \mathrm{t}-1$ and input DNA significantly impact enrichment efficiency in large-genome amphibians.

Results

45 Increasing the amounts of $\mathrm{c}_{0} \mathrm{t}-1$ and individual input DNA both reduce the rates of PCR 
bioRxiv preprint doi: https://doi.org/10.1101/021253; this version posted June 19, 2015. The copyright holder for this preprint (which was

not certified by peer review) is the author/funder, who has granted bioRxiv a license to display the preprint in perpetuity. It is made available under aCC-BY-NC-ND 4.0 International license.

Exon capture optimization in a large-genome amphibian

target sequences, essentially doubling overall efficiency of the target capture from $10.4 \%$ to nearly $19.9 \%$. We also found that post-enrichment DNA concentrations and qPCR enrichment verification were useful for predicting the success of enrichment.

\section{Conclusions}

1 Increasing the amount of individual sample input DNA and the amount of $\mathrm{c}_{0} \mathrm{t}-1$ blocker both increased the efficiency of target capture in large-genome salamanders. By reducing PCR duplication rates, the number of unique reads mapping to targets increased, making target capture experiments more efficient and affordable. Our results indicate that target capture protocols can be modified to efficiently screen large-genome vertebrate taxa including amphibians.

Keywords: Exon capture, large genome, amphibian, target enrichment

\section{Background}

Reduced representation sequencing technologies enrich DNA libraries for selected genomic regions, allowing researchers to attain higher sequencing depth over a predetermined subset of the genome for a given cost. Several techniques are now in widespread use in population genetics and evolutionary biology. The most popular of these include RAD-tag sequencing (which targets anonymous loci flanking restriction enzyme sites) [1] and target-enrichment approaches such as ultra-conserved element (UCE) sequencing (which targets regions of the genome that are highly-conserved between species) [2] and exome/exon sequencing (which target genomic regions that are expressed as RNAs).

These methods are all extremely useful for different purposes. RAD-tag sequencing is a cost-effective strategy for collecting information on thousands of anonymous loci for individuals within a population, but suffers from bias and large amounts of missing data, especially when divergent individuals are analyzed [3]. UCE sequencing, conversely, is 
bioRxiv preprint doi: https://doi.org/10.1101/021253; this version posted June 19,2015 . The copyright holder for this preprint (which was

not certified by peer review) is the author/funder, who has granted bioRxiv a license to display the preprint in perpetuity. It is made available under aCC-BY-NC-ND 4.0 International license.

Exon capture optimization in a large-genome amphibian

72 designed to generate relatively complete datasets across distantly related species using a single

73 test panel [2], but the biological function of these conserved loci are mostly unknown.

74 Exon capture differs from RAD-tag sequencing in that it targets predetermined sequence

75 regions, and is distinct from UCE sequencing in that it targets known gene regions that are

76 often assumed to be functionally important. As such, exon capture is a promising technology

77 for gathering large amounts of targeted genomic data for population-level studies exploring

78 patterns of population structure and natural selection [4-6]. It is particularly useful for

collecting data from species without assembled reference genomes, as the prerequisite genomic

information may be gathered from existing collections of expressed sequence tag (EST)

sequences or transcriptome sequencing [7, 8]. Enrichment of exon sequences has been

performed in multiple non-model species, with applications ranging from investigating sequences to be magnetically captured, and all non-hybridized DNA is washed away. reduce the efficiency of sequencing [10]. Because library fragments are often longer than the probe sequences, part of the hybridized library fragment is usually free to bind to other molecules in the pool. Since repetitive DNA sequences are by definition present at high concentrations in large-genome organisms, if this exposed region is from a repetitive element it has a high probability of binding to another such fragment and pulling it through to the final library pool. Adapter sequences are also present at very high concentrations, presenting another opportunity for molecules to bind to captured fragments, creating "daisy chains" of random 
bioRxiv preprint doi: https://doi.org/10.1101/021253; this version posted June 19,2015 . The copyright holder for this preprint (which was

not certified by peer review) is the author/funder, who has granted bioRxiv a license to display the preprint in perpetuity. It is made available under aCC-BY-NC-ND 4.0 International license.

Exon capture optimization in a large-genome amphibian

97 library molecules. To mitigate these factors, several "blockers," designed to hybridize to these

98 regions before the biotinylated probes are able to, are typically added to target capture

99 reactions. One such blocker, $\mathrm{c}_{0} \mathrm{t}-1$, is a solution of high-copy repetitive DNA fragments that

100 hybridizes with repetitive library fragments and blocks them from attaching to captured

101 fragments. For large-genome amphibians, repetitive elements are present at an even higher

102 concentration than normal [11], and we hypothesize that increasing the amount of $\mathrm{c}_{0} \mathrm{t}-1$ in

103 solution may improve hybridization efficiency. This process is shown in Figure 1.

104 Relatively few exon capture studies have been performed in amphibians [but see 9], likely

105 reflecting the reticence of many biologists to apply genomic approaches to their large, highly

106 repetitive genomes. While these large genomes, ranging up to 117 gigabases [12], currently

107 render full-genome sequencing approaches untenable, exon capture is well-suited to bridge the

108 gap between single-locus comparative studies and whole-genome analyses for these and other

109 large-genome diploid species. Several amphibian species have large collections of EST

110 sequences available [13-15], and sequencing of cDNA libraries with de novo transcriptome

111 assembly is becoming increasingly accessible for species that currently lack such resources.

112 Laboratory costs of exon capture experiments hinge largely on the efficiency of the

113 enrichment process. Increasing the percentage of reads "on target" (sequence reads that align to

114 regions targeted in the capture array) directly reduces the amount of sequencing required to

115 attain a desired coverage level. Off-target reads may be present for several reasons, including

116 non-specific hybridization of capture probes to off-target regions, hybridization of off-target

117 DNA to the ends of captured target fragments, and failure to wash away all DNA not

118 hybridized to capture probes following enrichment [10]. This process may be particularly

119 problematic in amphibians because their large genome size is often due to a massive increase

120 in the amount of repetitive DNA [11], which leads to an greatly increased concentration of off-

121 target DNA in solution relative to on-target fragments. 
bioRxiv preprint doi: https://doi.org/10.1101/021253; this version posted June 19,2015 . The copyright holder for this preprint (which was

not certified by peer review) is the author/funder, who has granted bioRxiv a license to display the preprint in perpetuity. It is made available under aCC-BY-NC-ND 4.0 International license.

Exon capture optimization in a large-genome amphibian

122 We conducted a series of experiments that seek to optimize existing protocols for exon

123 capture experiments for large-genome amphibians (and other taxa). Our focus is on three

124 different Ambystoma salamanders - the California tiger salamander (Ambystoma

125 californiense), the barred tiger salamander (Ambystoma mavortium), and an F1 hybrid between

126 the two (Ambystoma californiense x mavortium, referred to as F1). Given the enormous size of

127 their genomes (estimated at about 32 gigabases) and the observation that they, like many

128 amphibians, have genomes that are rich in repetitive DNA, we altered the amount of $\mathrm{c}_{0} \mathrm{t}-1$

129 blocker, under the assumption that highly-repetitive genomes may benefit from an increased

130 amount of repetitive sequence blocker. We also manipulated the amount of individual input

131 and total DNA in sequence capture reactions to manipulate the total number of copies of the

132 genome, estimating tradeoffs among multiplexibility and enrichment efficiency to maximize

133 the number of individuals that can be sequenced for each sequence capture reaction.

\section{Methods}

135 Array design and laboratory methods

136 We designed an array of 8,706 putative exons (8,706 distinct genes) using EST sequences

137 from the closely-related Mexican axolotl (Ambystoma mexicanum) [17]. Mitochondrial

138 sequence divergence between the California tiger salamander and the Mexican axolotl is

139 approximately $6.4 \%$, and is approximately $6.8 \%$ between the barred tiger salamander and

140 Mexican axolotl [18], suggesting that less-diverged nuclear exons from the axolotl should

141 serve as appropriate targets for our species. In our design, we attempted to avoid targeting

142 regions that span exon/intron boundaries, as these targets have been found to be much less

143 efficient [8]. Exon boundaries can be found by mapping EST sequences to a reference genome

144 while allowing for long gaps that represent introns. However, no salamander genome is

145 currently available, and the two available frog genomes (Xenopus tropicalus [19] and

146 Nanorana parkeri [20]) last shared a common ancestor with salamanders approximately 290 
bioRxiv preprint doi: https://doi.org/10.1101/021253; this version posted June 19, 2015. The copyright holder for this preprint (which was not certified by peer review) is the author/funder, who has granted bioRxiv a license to display the preprint in perpetuity. It is made available under aCC-BY-NC-ND 4.0 International license.

Exon capture optimization in a large-genome amphibian

147 million years ago [21]. To account for this, we developed a comparative method for

148 conservatively predicting intron splice sites within EST sequences (unpublished data). Target

149 sequences were an average of $290 \mathrm{bp}$ in length (minimum length=88 bp, maximum=450 bp,

150 standard deviation $=71 \mathrm{bp}$ ), for a total target region length of 2.53 megabases. A total of 39,984

$151 \quad 100 \mathrm{bp}$ probe sequences were tiled across these target regions at an average of $1.8 \mathrm{X}$ tiling

152 density. These probes were synthesized as biotinylated RNA oligos in a MYbaits kit

153 (MYcroarray, Ann Arbor, MI).

154 We extracted genomic DNA from three individual salamanders--one California tiger

155 salamander (Ambystoma californiense \#HBS127160 — CTS), one barred tiger salamander

156 (Ambystoma mavortium \#HBS127161-BTS), and one F1 hybrid between the two species

157 (\#HBS109668) — using a salt extraction protocol [22] and several independent extractions of

158 each individual to attain the amount needed for preparing several libraries. Extractions were

159 then combined into pools to draw from for library preparations. Two of these pools consisted

160 of pure California tiger salamander DNA or pure F1 DNA and are labeled CTS and F1,

161 respectively. The third pool, which was intended to be pure BTS, was found to consist of

162 roughly $70 \%$ barred tiger salamander DNA and 30\% California tiger salamander DNA,

163 apparently due to a pooling error (later verified through re-extraction of the original tissues

164 and Sanger sequencing). We refer to this pool as BTS*, and treat it as a third sample in our

165 experimental design. DNA was diluted to $20 \mathrm{ng} / \mu \mathrm{L}$ and sheared to roughly $500 \mathrm{bp}$ on a

166 BioRupter (Diagenode, Denville, NJ). For each of the 53 individual library preparations (Table

167 1), we used roughly 450 ng of DNA for library preparations. Standard Illumina library

168 preparations (end repair, A-tailing, and adapter ligation) were performed using Kapa LTP

169 library preparation kits (Kapa Biosystems, Wilmington, MA). Samples were dual-indexed with

$1708 \mathrm{bp}$ indices that were added via PCR (adapters from Travis Glenn, University of Georgia).

171 Following library preparation we performed a double-sided size selection with SPRI beads [23] 
bioRxiv preprint doi: https://doi.org/10.1101/021253; this version posted June 19,2015 . The copyright holder for this preprint (which was not certified by peer review) is the author/funder, who has granted bioRxiv a license to display the preprint in perpetuity. It is made available under aCC-BY-NC-ND 4.0 International license.

Exon capture optimization in a large-genome amphibian

172 to attain a fragment size distribution centered around $400 \mathrm{bp}$ and ranging from $200 \mathrm{bp}$ to 1,000

173 bp. Species-specific $\mathrm{c}_{0} \mathrm{t}-1$ was prepared using DNA extracted from a California tiger

174 salamander and a single-strand nuclease as follows: First, extracted DNA was treated with

175 RNase and brought to $500 \mu \mathrm{L}$ at $1,000 \mathrm{ng} / \mu \mathrm{L}$ in $1.2 X$ SSC. This DNA was then sheared on a

176 BioRuptor (Diagenode, Denville, NJ) to roughly 300bp. Next, the solution was denatured at

$17795 \mathrm{C}$ for 10 minutes, then partially renatured at $60 \mathrm{C}$ for 5 minutes and 45 seconds, placed on ice

178 for two minutes, then put in a $42 \mathrm{C}$ incubator. A preheated $250 \mu \mathrm{L}$ aliquot of $\mathrm{S} 1$ nuclease (in

179 buffer) was then added to the partially-renatured DNA and incubated for 1 hour at $42 \mathrm{C}$. The

180 DNA was then precipitated with $75 \mu \mathrm{L}$ of $3 \mathrm{M}$ sodium acetate and $750 \mu \mathrm{L}$ isopropanol and

181 centrifuged for 20 minutes at 14,000 RPM at 4C. Isopropanol was then removed and the pellet

182 was washed with $500 \mu \mathrm{L}$ cold $70 \%$ ethanol, centrifuged again at 14,000 RPM for 10 minutes

183 (4C), and dried following ethanol removal. We rehydrated this pellet with $50 \mu \mathrm{L}$ of $10 \mathrm{mM}$

184 Tris- $\mathrm{HCl}, \mathrm{pH} 8$, and dried down to the appropriate concentration (for $1 \mathrm{X} \mathrm{c}_{0} \mathrm{t}-1,500 \mathrm{ng} / \mu \mathrm{L}$; for

$1856 \mathrm{X}$ and $\left.12 \mathrm{X} \mathrm{c} \mathrm{c}_{0} \mathrm{t}-11,000 \mathrm{ng} / \mu \mathrm{L}\right)$.

186 We then multiplexed prepared libraries into capture reactions (Table 1). Total DNA input

187 into the sequence capture was either $500 \mathrm{ng}$ or $1,000 \mathrm{ng}$, and individual library input DNA for

188 multiplexing ranged from 20 to $1,000 \mathrm{ng}$ (Table 1). The repetitive DNA blocker $\mathrm{c}_{0} \mathrm{t}-1$ was

189 added to the 24 different capture reactions in one of three amounts-2,500 ng, 15,000 ng, or

$19030,000 \mathrm{ng}$, corresponding to $1 \mathrm{X}, 6 \mathrm{X}$, and 12X protocol recommendation. Libraries were

191 enriched using the MYbaits protocol (version 2.3.1), hybridizing probes for 24.5 hours and

192 implementing the optional high-stringency washes. Following the three wash steps in the

193 MYbaits protocol, we amplified the remaining enriched DNA (with streptavidin beads still in

194 solution) using 14 cycles of PCR. Multiple separate PCR reactions were performed for each

195 capture reaction, which were subsequently pooled after amplification to reduce PCR

196 amplification bias [24]. 
bioRxiv preprint doi: https://doi.org/10.1101/021253; this version posted June 19,2015 . The copyright holder for this preprint (which was

not certified by peer review) is the author/funder, who has granted bioRxiv a license to display the preprint in perpetuity. It is made available under aCC-BY-NC-ND 4.0 International license.

Exon capture optimization in a large-genome amphibian

197

Post-capture, post-PCR libraries were quantitated and characterized with qPCR using the Kapa Illumina library quantification kit (PicoGreen ${ }^{\circledR}$ Life Technologies, Grand Island, NY and Kapa Biosystems, Wilmington, MA) on a LightCycler 480 (Roche, Basel, Switzerland). We also visualized fragment size distributions using a BioAnalyzer 2100 DNA HS chip (Agilent, Santa Clara, CA). All capture reactions were tested for preliminary evidence of enrichment via qPCR. We developed five primer pairs derived from different test loci chosen from our targets as positive controls, and one primer pair derived from a mitochondrial locus we were not targeting as a negative control. We used these to measure the relative concentrations of target molecules in solution by calculating the mean number of cycles required for qPCR reactions to reach the crossing point $\left(C_{p}\right)$ in libraries pre and post enrichment. Changes in $\left(C_{p}\right)$ were measured for each test locus for all samples and averaged across all five test loci. For targeted loci, we expected that the number of cycles needed to reach this point would decrease, because target sequences would be present in higher concentrations. Conversely, we expected the number of cycles for the mitochondrial DNA locus to increase after enrichment, because that sequence was not targeted and we expected its concentration to decrease.

All capture reactions were then combined together for sequencing on an Illumina HiSeq 2500 with $150 \mathrm{bp}$ paired-end reads. Reactions were pooled such that all individual libraries would receive at least 1.5 million reads. Because some capture reactions contained samples with more DNA compared to other samples in the pool, some capture reactions were assigned more of the sequencing lane than others (Table 1). Sample pooling and sequencing was performed at the Vincent J. Coates Genomics Sequencing Laboratory at UC Berkeley.

\section{Genetic data analysis}

Demultiplexed reads were checked for adapter contamination and quality trimmed using Trimmomatic 0.32 [25]. Quality trimming was performed using several criteria. First, leading base pairs with a phred score less than 5 were removed. Next, trailing (3') base pairs with a 
bioRxiv preprint doi: https://doi.org/10.1101/021253; this version posted June 19,2015 . The copyright holder for this preprint (which was

not certified by peer review) is the author/funder, who has granted bioRxiv a license to display the preprint in perpetuity. It is made available under aCC-BY-NC-ND 4.0 International license.

Exon capture optimization in a large-genome amphibian

222 phred score less than 15 were removed. Finally, we used a four base pair sliding window (5' to

223 3'), trimming all trailing bases when the average phred score within that window dropped

224 below 20. We discarded all reads under $40 \mathrm{bp}$ after trimming, and overlapping reads were

225 merged using fastq-join [26].

226 Genetic data from all of the Califonia tiger salamander libraries were combined for

227 assembly to create the most complete possible single-species de novo assembly of our target

228 regions. Targets were de novo assembled using the Assembly by Reduced Complexity (ARC)

229 pipeline [27]. This assembly pipeline separates reads that align to target regions and performs

230 small, target-specific de novo assemblies on these read pools. Each assembled contig then

231 replaces its original target sequence, and the process is repeated iteratively. Within ARC, read

232 mapping was performed using bowtie2 [28], error correction with BayesHammer [29], and

233 assemblies were generated using SPAdes [30]. The ARC pipeline was run for six iterations,

234 which was enough to exhaust all of the reads assignable to most targets.

235 Following assembly, all contigs were compared against the original target sequences using

236 blastn [31], and reciprocal best blast hits (RBBHs) were found [32]. Chimeric assemblies are

237 pervasive and problematic for studies that involve de novo assembly of target sequences,

238 because they can insert repetitive sequences into the contigs, making it appear that many reads

239 are mapping to a target when those reads are actually from repetitive regions in the genome

240 (for instance, see the coverage across the non chimera-masked contig in Figure 2). To attempt

241 to reduce the presence of chimeric assemblies and repetitive sequences in our data, the RBBHs

242 were blasted to themselves (blastn e-value of 1e-20), and base pairs in sequence regions that

243 positively matched other targets were replaced with N's. These chimera-masked RBBHs

244 served as our final assembled target set.

245 After assembly, reads from each individual were mapped against the chimera-masked

246 RBBH target set using bwa mem [33]. BAM file conversion, sorting, and merging was done 
bioRxiv preprint doi: https://doi.org/10.1101/021253; this version posted June 19,2015 . The copyright holder for this preprint (which was

not certified by peer review) is the author/funder, who has granted bioRxiv a license to display the preprint in perpetuity. It is made available under aCC-BY-NC-ND 4.0 International license.

Exon capture optimization in a large-genome amphibian

247 using SAMtools v1.0 [34]. PCR duplicates were marked using picard tools v. 1.119

248 (http://broadinstittute.github.io/picard) which finds reads or read pairs that have identical 5'

249 and 3' mapping coordinates, with the reasoning that two chromosome copies are unlikely to

250 shear in the exact same positions during random sonication. Under this assumption, reads or

251 read pairs that have identical 5' and 3' mapping coordinates likely result from sequencing

252 multiple amplified copies of the same original DNA molecule, which is undesirable. Finally,

253 mapping rates and PCR duplication rates were inferred by counting the relevant SAM flags

254 using SAMtools flagstat [34].

255 In addition to measuring the total percentage of unique reads that mapped to target regions,

256 target-level performance was also evaluated. Because most targets showed a characteristic

257 peak of read depth centered over the middle of the target where probes were tiled, and because

258 a few targets maintained confounding repetitive sequences at the periphery of the assembled

259 contigs, we characterized the read depths of targets over bases that had direct overlap with our

260 target probes. That is, for target-level metrics, we did not consider read depth for the flanking

261 regions that are naturally appended to the ends of each target during the assembly process. For

262 each individual library preparation, we calculated the average unique-read sequencing depth

263 across a) the entire target regions and b) across the $100 \mathrm{bp}$ window within each target that had

264 the highest average coverage. For all read depth comparisons, depths were corrected for the

265 total number of reads a library received in sequencing by multiplying by a scaling factor $\mathrm{n}_{\mathrm{f}} / \mathrm{n}_{\mathrm{i}}$,

266 where $n_{f}$ is the fewest number of reads received by any individual in the experiment and $n_{i}$ is

267 the number of reads received by the individual under consideration. Assembled target

268 sequences less than $100 \mathrm{bp}$ were not included in read depth calculations because $100 \mathrm{bp}$ is

269 significantly less than the average read length and these targets tended to recruit very few

270 reads. 
bioRxiv preprint doi: https://doi.org/10.1101/021253; this version posted June 19,2015 . The copyright holder for this preprint (which was

not certified by peer review) is the author/funder, who has granted bioRxiv a license to display the preprint in perpetuity. It is made available under aCC-BY-NC-ND 4.0 International license.

Exon capture optimization in a large-genome amphibian

271 Assessing the importantance of $c_{0}$ t-1 and individual input DNA amounts

272 Linear regression was used to quantify the relationships between $\mathrm{c}_{0} \mathrm{t}-1$ and individual input

273 DNA to the percentage of unique reads that mapped to targets. Because three different

274 biological individuals were used for library preparations in this experiment, we also included

275 the identity of the individual as a possible source of variation to explain enrichment efficiency.

276 Models were built that included different combinations of $\mathrm{c}_{0} \mathrm{t}-1$, individual input DNA, and the

277 identity of the individual (CTS, BTS*, or F1) as predictor variables, and unique reads mapping

278 to targets as the response variable. A similar approach was used to model the average

279 sequencing depths across all targets. All models were evaluated by examining the regression

280 coefficients, adjusted $\mathrm{R}^{2}$, and AIC values.

\section{Results}

282 Pre-sequencing library quantitation

283 DNA concentration yields for post-enrichment, post-PCR samples were lower than

284 anticipated. After 14 PCR cycles, amplified enrichment pools contained an average of $279.5 \mathrm{ng}$

285 of DNA (after amplifying $15 \mu \mathrm{L}$ out of a total $33 \mu \mathrm{L}$ in the post-enrichment pools with a $50 \mu \mathrm{L}$

286 PCR reaction). One capture reaction (Library \# 18, see Table 2) had a much higher yield after

287 post-enrichment PCR (2,150 ng). Mean $\mathrm{C}_{\mathrm{p}}$ in $\mathrm{qPCR}$ enrichment verification reactions

288 decreased by an average of 9.1 cycles across the five test loci after enrichment, while the

289 number of cycles required for amplification of a non-targeted negative control locus increased

290 by an average of 2.17 cycles. We found a positive correlation between the mean change in $C_{p}$

291 averaged across the five test loci and the raw percentage of reads on target after sequencing for

292 each library (Figure 3, adjusted $\mathrm{R}^{2}=0.1136, \mathrm{p}=0.00784$ ), although the relationship was

293 stronger between post-enrichment, post-PCR DNA concentration and raw mapping rate (Figure

294 4, adjusted $\left.\mathrm{R}^{2}=0.224, \mathrm{p}=0.000204\right)$. 
bioRxiv preprint doi: https://doi.org/10.1101/021253; this version posted June 19,2015 . The copyright holder for this preprint (which was

not certified by peer review) is the author/funder, who has granted bioRxiv a license to display the preprint in perpetuity. It is made available under aCC-BY-NC-ND 4.0 International license.

Exon capture optimization in a large-genome amphibian

295

296

297

298

299

300

301

302

303

304

305

306

307

308

309

\section{Sequence data}

We generated 45,641,469,300 base pairs of sequence data in the form of 150bp paired-end reads. All libraries received at least 1,207,605 read pairs passing filter (mean=2,766,149 read pairs, $s d=1,582,161$ read pairs). Average base quality phred scores for samples ranged from 33.6 to $34.8($ mean $=34.4, \mathrm{sd}=0.29)$. An average of $93 \%$ of all read pairs both passed the Trimmomatic filter, whereas $5.2 \%$ of all read pairs had either the forward or reverse read removed, and $1.8 \%$ had both members removed. Because our insert size was mostly larger than $300 \mathrm{bp}$ (which is two times the read length), fastq-join did not merge most reads — percentages of joined reads ranged from $24.0 \%$ to $35.1 \%$ for the different samples. Nuclear sequence divergence between the Mexican axolotl (the species from which probes were designed) and California tiger salamander in the exon targets averaged $1.84 \%$.

Reference assembly and read mapping

A total of 78,674,304 reads (all of the reads from the CTS individual) representing 11,960,279,114 bp were supplied to ARC for de novo assembly of targets. An average of 905 reads in iteration $1,1,496$ reads in iteration $2,1,999$ reads in iteration $3,4,485$ reads in iteration $4,8,132$ reads in iteration 5, and 11,199 reads in iteration 6 were assigned to each target for de novo assembly. The final assembly, after six iterations of the ARC assembly pipeline, contained 120,617 sequences for a total of $69,873,191 \mathrm{bp}$. After blasting the target sequences to the assembly and vice versa, we found a total of $8,386 \mathrm{RBBHs}$, or $96.3 \%$ of all targets. These assembled target contigs were $1,409 \mathrm{bp}$ on average, for a total reference length of $11,813,341 \mathrm{bp}$. This average extension of 1,119 to each target sequence was expected, as the insert size in our genomic library preparations ranged up to roughly $550 \mathrm{bp}$. Thus $550 \mathrm{bp}$ fragments that contained target sequence on either end could still be hybridized by the capture probes and their sequence at the other end recruited into the target assembly. Self-blasting the target RBBHs to one another resulted in 1,060 targets that also had hits with other targets. A 
bioRxiv preprint doi: https://doi.org/10.1101/021253; this version posted June 19,2015 . The copyright holder for this preprint (which was

not certified by peer review) is the author/funder, who has granted bioRxiv a license to display the preprint in perpetuity. It is made available under aCC-BY-NC-ND 4.0 International license.

Exon capture optimization in a large-genome amphibian

320 total of $361,949 \mathrm{bp}$ of such overlap was found between targets, and the overlapping bases were

321 replaced with N's to reduce the effects of repetitive sequences and chimeric assemblies.

322 An average of $18.21 \%$ of all reads across samples mapped to the chimera-masked reciprocal

323 blast hit target assembly. Individual sample raw read mapping rates ranged from $6.7 \%$ to

$32434.8 \%$ (Table 2). The percentage of PCR duplicates present also varied widely across samples, 325 ranging from $8.5 \%$ to $48.6 \%$ (mean $=24.5 \%, \mathrm{sd}=11.7 \%)$. After subtracting PCR duplicates from 326 mapped reads, the percentage of unique reads on target varied between $5.4 \%$ and $30.8 \%$, with a 327 mean of $14.0 \%$ and standard deviation of $4.4 \%$ (Table 2 ).

328 Target-level metrics indicated that some targets performed significantly better than others

329 (Figure 5). To control for variation in the number of reads received between samples, all

330 libraries had their depths corrected to what would have been observed if they had received the

331 same number of reads as the least-sequenced library in this study. To give an idea of the

332 sequencing effort required to generate the depths listed below, this corresponded to

333 approximately 2.4 million 150 bp reads against just over 2.5 million bp of total target

334 sequence. Among all libraries, the average depth across target sequences was $7.99(\mathrm{sd}=3.33)$,

335 and the average for the highest $100 \mathrm{bp}$ window within targets was $9.50(\mathrm{sd}=3.89)$. A total of

3365,648 targets had a sequencing-effort corrected average depth across the target region greater

337 than 5, and 2,283 had average depths greater than 10. For the $100 \mathrm{bp}$ windows with the greatest

338 depth for each target, 6,100 had depths greater than 5 and 3,313 had depths greater than 10.

339 Effects of $c_{0}$ t-1 and input DNA amount in capture reactions

340 All models that incorporated the identity of the individual DNA pool underperformed

341 (higher AIC value) nested models that did not incorporate information regarding the identity of

342 the input DNA. Because of this, and because slope coefficients for the identity term in all

343 models was never significant ( $\mathrm{p}=0.44$ or greater), the identity of the individual did not 
bioRxiv preprint doi: https://doi.org/10.1101/021253; this version posted June 19,2015 . The copyright holder for this preprint (which was

not certified by peer review) is the author/funder, who has granted bioRxiv a license to display the preprint in perpetuity. It is made available under aCC-BY-NC-ND 4.0 International license.

Exon capture optimization in a large-genome amphibian

344 significantly impact capture efficiency or read mapping, and models including this variable are 345 not included in the summary tables.

346 Increasing the amount of individual input DNA and the amount of $\mathrm{c}_{0} \mathrm{t}-1$ blocker were both

347 associated with higher percentages of unique reads on target and higher realized sequence

348 depth across targets (Tables 3 and 4, Figure 6). Linear regression recovered positive and

349 significant slopes for both variables separately and when combined in multiple linear

350 regression. Models predict an extra $1 \%$ unique reads on target for every $166 \mathrm{ng}$ of extra

351 individual input DNA $(\mathrm{p}=0.000672)$ or every $6,750 \mathrm{ng}$ of extra $\mathrm{c}_{0} \mathrm{t}-1$ blocker $(\mathrm{p}=0.00896)$

352 used in enrichment reactions. Regression coefficients for models that contained both individual

353 input DNA and $\mathrm{c}_{0} \mathrm{t}-1$ were quite similar to the single-variable model, differing by less than $3 \%$.

354 Individual input DNA and $\mathrm{c}_{0} \mathrm{t}-1$ did a better job predicting the percentage of unique reads on

355 target than the average depth across target regions (adjusted $\mathrm{R}^{2}$ of 0.325 vs 0.252 for the

356 combined models). Finally, the models that contained both input DNA and $\mathrm{c}_{0} \mathrm{t}-1$ as variables

357 had better AIC scores and $\mathrm{R}^{2}$ values than the nested single-variable models (see Figure 7), and

358 within the single-variable tests individual input DNA models outperformed $\mathrm{c}_{0} \mathrm{t}-1$ models for

359 both success measures in AIC and $\mathrm{R}^{2}$ (Tables 3 and 4).

\section{Discussion}

361 Perhaps the most important conclusion from this experiment is that target capture

362 experiments can indeed be successful in large-genome amphibians. This was not at all obvious

363 based on prior work on these organisms, and our hope is that others will use these results to

364 bring amphibians into the realm of population and phylogenomic analyses. The percentage of

365 unique reads on target is the most important summary metric for enrichment, as it is essentially

366 one minus the high quality data from the sequencer that is discarded. Our average percentage

367 of unique reads on target across all library treatments was $14 \%$; only three libraries were under

$3689 \%$, while our four best-performing libraries were all over $20 \%$. These numbers suggest that it 
Exon capture optimization in a large-genome amphibian

369 is reasonable to sequence 50 to 100 samples on a single HiSeq lane for a capture array size

370 similar to ours (2.5 megabases), depending on array configuration and coverage requirements.

371 Our rates of unique reads on target are in line with several other non-model exon capture

372 studies for species with smaller genomes. For instance, Hedtke et al. designed Agilent probes

373 from the Xenopus tropicalus genome and enriched libraries from two smaller-genome frogs,

374 achieving rates of $7.4 \%$ unique reads on target in Pipa pipa and $47.8 \%$ in Xenopus tropicalus

375 [9]. Bi et al. recovered $25.6 \%$ to $29.1 \%$ unique reads on target for an exon capture study in

376 chipmunks [7]. Similarly, Cosart et al. designed an Agilent exon capture microarray from the

377 Bos taurus genome and attained 20\%-29\% unique read mapping percentages in Bos taurus,

378 Bos indicus, and Bison bison for a similarly-sized target array as this study [35]. Finally, Neves

379 et al. reached 50\% raw mapping rates in multiplexed exon capture experiments in Pinus taeda,

380 a pine species with a roughly $21 \mathrm{gb}$ genome (approximately $2 / 3$ of the size of the salamander

381 genomes in this study), although they did not report percentages of unique reads on target or

382 levels of PCR duplication [8]. Several factors may be important in explaining these results,

383 including a potential negative relationship between the phylogenetic distance to the species

384 from which the capture array was developed and the percentage of unique reads on target, and

385 the size of the genome under investigation. As more target capture studies are reported across

386 diverse non-model taxa, we will better understand the relationship between genome size and

387 enrichment efficiency, as well as the effects of designing capture probes from divergent taxa.

388 Human exome capture studies, which typically use predesigned sequence capture arrays

389 across one of several different technologies (e.g. Truseq, Nimblegen, Agilent, or Nextera

390 exome capture kits) often attain percentages of unique reads on target in the range of $40 \%$ to

$39170 \%$ or higher $[36,37]$. This suggests that working from a well-assembled genome of the study

392 species helps to increase the number of reads on target substantially. However, the high

393 numbers in human experiments are likely also a function of the technologies used and the 
bioRxiv preprint doi: https://doi.org/10.1101/021253; this version posted June 19, 2015. The copyright holder for this preprint (which was

not certified by peer review) is the author/funder, who has granted bioRxiv a license to display the preprint in perpetuity. It is made available under aCC-BY-NC-ND 4.0 International license.

Exon capture optimization in a large-genome amphibian

394 many iterations of probe set optimization experiments that have been conducted, and these may

395 not be feasible in non-human systems.

396 We found evidence that increasing $\mathrm{c}_{0} \mathrm{t}-1$ and individual input DNA into sequence capture

397 reactions increased the percentage of unique reads mapping to targets in large-genome

398 salamanders. As can be seen in Figure 6, this effect was driven largely by the correlation of

399 these two variables with the reduction in PCR duplication rates. Because duplicate reads (reads

400 with the same 5' and 3' mapping coordinates) are typically removed prior to genotyping

401 analyses, lowering duplication rates as much as possible is critical for increasing the efficiency,

402 and therefore reducing the sequencing costs of target enrichment studies. In addition to

403 considering the variables tested here, researchers should also consider paired-end sequencing

404 whenever possible in exon capture studies, as single-end reads have a much higher false

405 identification rate of PCR duplication [38].

406 The low yields of DNA after enrichment and PCR are interesting. We speculate that they

407 may be a consequence of libraries prepared from large genomes containing relatively low

408 absolute numbers of on-target fragments in the pools during enrichment, so that a higher

409 percentage of the pool is washed away. While qPCR of pre- and post-enrichment libraries

410 using primers meant to amplify targeted regions is a useful way to test enrichment efficiency,

411 we found that post-enrichment DNA concentrations may also be informative as to whether or

412 not enrichment was successful for large-genome amphibians with this protocol (Figure 4).

413 Also, we note that Library \#18, which had a very high post-enrichment post-PCR DNA

414 concentration, showed correspondingly low performance in terms of percentage of raw and

415 unique reads on target (5.4\% unique read mapping rate). This suggests that for this reaction,

416 off-target fragments may not have been efficiently removed during the post-enrichment

417 washing steps. 
bioRxiv preprint doi: https://doi.org/10.1101/021253; this version posted June 19,2015 . The copyright holder for this preprint (which was

not certified by peer review) is the author/funder, who has granted bioRxiv a license to display the preprint in perpetuity. It is made available under aCC-BY-NC-ND 4.0 International license.

Exon capture optimization in a large-genome amphibian

418 After duplicate removal, we observed a greater than five-fold difference in unique read

419 mapping percentages (from 5.4\% to 30.8\%) among the samples tested in this experiment.

420 While even the low end of our enrichment efficiency values are encouraging for future exon

421 capture studies in large-genome amphibians, regularly attaining unique reads on target

422 percentages at the upper end of our success rate would lead to a concurrent $5 \mathrm{X}$ reduction in

423 sequencing costs for a given target coverage depth. In the future, we would like to test the

424 effects of increasing the amount of DNA (and therefore number of genome copies) used for

425 library preparations, as well as increasing the total amount of DNA in a single enrichment

426 reaction above the $1,000 \mathrm{ng}$ used here, with the hope that both of these steps will further reduce

427 PCR duplication rates.

\section{Conclusions}

429 Exon capture is a viable technology for gathering data from thousands of nuclear loci in

430 large numbers of individuals for salamanders and other taxa with large (at least $30 \mathrm{gb}$ ), highly

431 repetitive genomes. We recommend using at least $30,000 \mathrm{ng}$ of species-specific $\mathrm{c}_{0} \mathrm{t}-1$ blocker,

432 and as much input DNA as possible for each individual multiplexed into a capture reaction

433 when working with large-genome species. Ongoing research in our lab to further optimize

434 large genome target capture is focusing on the tradeoffs of different multiplexing regimes and

435 the tradeoffs from increasing the total amoung of DNA going into capture reactions and

436 individual library preparations (Figure 1). Although we can only speak directly to experiments

437 that utilize custom MYbaits exon enrichment reactions, we see no reason why our results

438 should not generalize to other platforms such as UCEs [2].

439 As large-scale sequencing projects become the norm for data acquisition in non-model

440 systems, it is crucial to build a body of literature with standard reporting metrics for both

441 laboratory procedures and data filtering and analysis. Gathering information about best

442 practices in custom array target enrichment from experiments in the literature is difficult due to 
bioRxiv preprint doi: https://doi.org/10.1101/021253; this version posted June 19, 2015. The copyright holder for this preprint (which was

not certified by peer review) is the author/funder, who has granted bioRxiv a license to display the preprint in perpetuity. It is made available under aCC-BY-NC-ND 4.0 International license.

Exon capture optimization in a large-genome amphibian

443 the lack of standardization in reporting metrics. At a minimum, we suggest that researchers

444 report raw mapping rates to target sequences, PCR duplication rates (ideally based on paired-

445 end reads), and average depths across the different targets, including standard deviations, for a

446 given sequencing effort. Standardized metrics will allow researchers to evaluate whether a

447 particular probe set may work in their study system and how much sequencing may be needed.

448 We hope that this study can help set a precedent for such reporting on successful laboratory

449 procedures, including a thorough discussion of efficiency and success of target capture in non-

450 model organisms.

\section{Availability of supporting data}

The data set supporting the results of this article is available at Genbank:PRJNA285335.

The target sequences used for this study, the corresponding Ambystoma mexicanum-derived capture probes, and the source code used to analyze the data from this experiment are available at http://dx.doi.org/10.5281/zenodo.18587 [39].

\section{Competing interests}

458 The authors declare that they have no competing interests.

\section{9}

\section{Authors' contributions}

460 EMM contributed to the design of the study, performed some of the molecular work,

461 analysed the results, and wrote the manuscript. GGM contributed to the design of the study,

462 performed most of the laboratory work, and revised the manuscript. HBS contributed to the

463 design of the study and interpretation of results, and revised the manuscript. All authors read

464 and approved the final manuscript. 
bioRxiv preprint doi: https://doi.org/10.1101/021253; this version posted June 19, 2015. The copyright holder for this preprint (which was not certified by peer review) is the author/funder, who has granted bioRxiv a license to display the preprint in perpetuity. It is made available under aCC-BY-NC-ND 4.0 International license.

Exon capture optimization in a large-genome amphibian

465

466

467

\section{Acknowledgements}

We thank Randal Voss for the Ambystoma mexicanum sequences used to design the capture array, and Brant Faircloth for input on experimental design and laboratory troubleshooting. Animal work was conducted under California Department of Fish and Wildlife permit \#SC2480 and associated MOU, USFWS permit \#TE-094642-9, and UCLA IACUC protocol \#2013-011. This experiment used the Vincent J. Coates Genomics Sequencing Laboratory at UC Berkeley, supported by NIH S10 Instrumentation Grants S10RR029668 and S10RR027303. EMM and HBS are supported by NSF-DEB 1257648.

\section{References}

1. Miller MR, Dunham JP, Amores A, Cresko WA, Johnson EA: Rapid and cost-effective polymorphism identification and genotyping using restriction site associated DNA (RAD) markers. Genome Res 2007, 17:240-248.

2. Faircloth BC, McCormack JE, Crawford NG, Harvey MG, Brumfield RT, Glenn TC: Ultraconserved Elements Anchor Thousands of Genetic Markers Spanning Multiple Evolutionary Timescales. Syst Biol 2012:sys004.

3. Arnold B, Corbett-Detig RB, Hartl D, Bomblies K: RADseq underestimates diversity and introduces genealogical biases due to nonrandom haplotype sampling. Mol Ecol 2013, 22:3179-3190.

4. Hodges E, Xuan Z, Balija V, Kramer M, Molla MN, Smith SW, Middle CM, Rodesch MJ, Albert TJ, Hannon GJ, McCombie WR: Genome-wide in situ exon capture for selective resequencing. Nat Genet 2007, 39:1522-1527.

5. Yi X, Liang Y, Huerta-Sanchez E, Jin X, Cuo ZXP, Pool JE, Xu X, Jiang H, Vinckenbosch N, Korneliussen TS, Zheng H, Liu T, He W, Li K, Luo R, Nie X, Wu H, Zhao M, Cao H, Zou J, Shan Y, Li S, Yang Q, Asan, Ni P, Tian G, Xu J, Liu X, Jiang T, Wu R, et al.: Sequencing of 50 Human Exomes Reveals Adaptation to High Altitude. Science 2010, 329:75-78.

6. Zhou L, Bawa R, Holliday JA: Exome resequencing reveals signatures of demographic and adaptive processes across the genome and range of black cottonwood (Populus trichocarpa). Mol Ecol 2014, 23:2486-2499.

7. Bi K, Vanderpool D, Singhal S, Linderoth T, Moritz C, Good JM: Transcriptome-based exon capture enables highly cost-effective comparative genomic data collection at moderate evolutionary scales. BMC Genomics 2012, 13:403.

8. Neves LG, Davis JM, Barbazuk WB, Kirst M: Whole-exome targeted sequencing of the uncharacterized pine genome. Plant J 2013, 75:146-156. 
bioRxiv preprint doi: https://doi.org/10.1101/021253; this version posted June 19,2015 . The copyright holder for this preprint (which was not certified by peer review) is the author/funder, who has granted bioRxiv a license to display the preprint in perpetuity. It is made available under aCC-BY-NC-ND 4.0 International license.

Exon capture optimization in a large-genome amphibian

9. Hedtke SM, Morgan MJ, Cannatella DC, Hillis DM: Targeted enrichment: Maximizing orthologous gene comparisons across deep evolutionary time. PLOS ONE 2013, 8:e67908.

10. Hodges E, Rooks M, Xuan Z, Bhattacharjee A, Gordon DB, Brizuela L, McCombie WR, Hannon GJ: Hybrid selection of discrete genomic intervals on custom-designed microarrays for massively parallel sequencing. Nat Protoc 2009, 4:960-974.

11. Straus NA: Comparative DNA renaturation kinetics in amphibians. Proc Natl Acad Sci U S A 1971, 68:799-802.

12. Gregory TR: Genome size and developmental complexity. Genetica 2002, 115:131-146.

13. Zhang Z, Zhang B, Nie X, Liu Q, Xie F, Shang D: Transcriptome Analysis and Identification of Genes Related to Immune Function in Skin of the Chinese Brown Frog. Zoolog Sci 2009, 26:80-86.

14. Abdullayev I, Kirkham M, Björklund ÅK, Simon A, Sandberg R: A reference transcriptome and inferred proteome for the salamander Notophthalmus viridescens. Exp Cell Res 2013, 319:1187-1197.

15. Robertson LS, Cornman RS: Transcriptome resources for the frogs Lithobates clamitans and Pseudacris regilla, emphasizing antimicrobial peptides and conserved loci for phylogenetics. Mol Ecol Resour 2014, 14:178-183.

16. Zhao F, Yan C, Wang X, Yang Y, Wang G, Lee W, Xiang Y, Zhang Y: Comprehensive Transcriptome Profiling and Functional Analysis of the Frog (Bombina maxima) Immune System. DNA Res 2013:dst035.

17. Smith JJ, Kump DK, Walker JA, Parichy DM, Voss SR: A Comprehensive Expressed Sequence Tag Linkage Map for Tiger Salamander and Mexican Axolotl: Enabling Gene Mapping and Comparative Genomics in Ambystoma. Genetics 2005, 171:1161-1171.

18. Samuels AK, Weisrock DW, Smith JJ, France KJ, Walker JA, Putta S, Voss SR: Transcriptional and phylogenetic analysis of five complete ambystomatid salamander mitochondrial genomes. Gene 2005, 349:43-53.

19. Hellsten U, Harland RM, Gilchrist MJ, Hendrix D, Jurka J, Kapitonov V, Ovcharenko I, Putnam NH, Shu S, Taher L, Blitz IL, Blumberg B, Dichmann DS, Dubchak I, Amaya E, Detter JC, Fletcher R, Gerhard DS, Goodstein D, Graves T, Grigoriev IV, Grimwood J, Kawashima T, Lindquist E, Lucas SM, Mead PE, Mitros T, Ogino H, Ohta Y, Poliakov AV, et al.: The genome of the western clawed frog Xenopus tropicalis. Science 2010, 328:633-636.

20. Sun Y-B, Xiong Z-J, Xiang X-Y, Liu S-P, Zhou W-W, Tu X-L, Zhong L, Wang L, Wu DD, Zhang B-L, Zhu C-L, Yang M-M, Chen H-M, Li F, Zhou L, Feng S-H, Huang C, Zhang GJ, Irwin D, Hillis DM, Murphy RW, Yang H-M, Che J, Wang J, Zhang Y-P: Whole-genome sequence of the Tibetan frog Nanorana parkeri and the comparative evolution of tetrapod genomes. Proc Natl Acad Sci 2015, 112:E1257-E1262.

21. San Mauro D: A multilocus timescale for the origin of extant amphibians. $\mathrm{Mol}$ Phylogenet Evol 2010, 56:554-561. 
bioRxiv preprint doi: https://doi.org/10.1101/021253; this version posted June 19, 2015. The copyright holder for this preprint (which was not certified by peer review) is the author/funder, who has granted bioRxiv a license to display the preprint in perpetuity. It is made available under aCC-BY-NC-ND 4.0 International license.

Exon capture optimization in a large-genome amphibian

22. Sambrook J, Russell DW, Russell DW: Molecular Cloning: A Laboratory Manual (3Volume Set). Volume 999. Cold spring harbor laboratory press Cold Spring Harbor, New York:; 2001.

23. Bronner IF, Quail MA, Turner DJ, Swerdlow H: Improved Protocols for Illumina Sequencing. Curr Protoc Hum Genet Editor Board Jonathan Haines Al 2009, 018.

24. Barnard R, Futo V, Pecheniuk N, Slattery M, Walsh T: PCR bias toward the wild-type kras and p53 sequences: implications for PCR detection of mutations and cancer diagnosis. BioTechniques 1998, 25:684-691.

25. Bolger AM, Lohse M, Usadel B: Trimmomatic: A flexible trimmer for Illumina Sequence Data. Bioinformatics 2014:btu170.

26. Aronesty E: Comparison of sequencing utility programs. Open Bioinforma J 2013, 7:18 .

27. Hunter SS, Lyon RT, Sarver BAJ, Hardwick K, Forney LJ, Settles ML: Assembly by Reduced Complexity (ARC): a hybrid approach for targeted assembly of homologous sequences. bioRxiv 2015:014662.

28. Langmead B, Salzberg SL: Fast gapped-read alignment with Bowtie 2. Nat Methods 2012, 9:357-359.

29. Nikolenko SI, Korobeynikov AI, Alekseyev MA: BayesHammer: Bayesian clustering for error correction in single-cell sequencing. BMC Genomics 2013, 14(Suppl 1):S7.

30. Bankevich A, Nurk S, Antipov D, Gurevich AA, Dvorkin M, Kulikov AS, Lesin VM, Nikolenko SI, Pham S, Prjibelski AD, others: SPAdes: a new genome assembly algorithm and its applications to single-cell sequencing. J Comput Biol 2012, 19:455-477.

31. Camacho C, Coulouris G, Avagyan V, Ma N, Papadopoulos J, Bealer K, Madden TL: BLAST+: architecture and applications. BMC Bioinformatics 2009, 10:421.

32. Rivera MC, Jain R, Moore JE, Lake JA: Genomic evidence for two functionally distinct gene classes. Proc Natl Acad Sci U S A 1998, 95:6239-6244.

33. Li H: Aligning sequence reads, clone sequences and assembly contigs with BWAMEM. ArXiv13033997 Q-Bio 2013.

34. Li H, Handsaker B, Wysoker A, Fennell T, Ruan J, Homer N, Marth G, Abecasis G, Durbin R, others: The sequence alignment/map format and SAMtools. Bioinformatics 2009, 25:2078-2079.

35. Cosart T, Beja-Pereira A, Chen S, Ng SB, Shendure J, Luikart G: Exome-wide DNA capture and next generation sequencing in domestic and wild species. BMC Genomics 2011, 12:347.

36. Chilamakuri CSR, Lorenz S, Madoui M-A, Vodák D, Sun J, Hovig E, Myklebost O, MezaZepeda LA: Performance comparison of four exome capture systems for deep sequencing. BMC Genomics 2014, 15:449. 
bioRxiv preprint doi: https://doi.org/10.1101/021253; this version posted June 19, 2015. The copyright holder for this preprint (which was

not certified by peer review) is the author/funder, who has granted bioRxiv a license to display the preprint in perpetuity. It is made available under aCC-BY-NC-ND 4.0 International license.

Exon capture optimization in a large-genome amphibian

573 37. Bodi K, Perera AG, Adams PS, Bintzler D, Dewar K, Grove DS, Kieleczawa J, Lyons RH, 574 Neubert TA, Noll AC, Singh S, Steen R, Zianni M: Comparison of Commercially Available 575 Target Enrichment Methods for Next-Generation Sequencing. J Biomol Tech JBT 2013, $576 \quad 24: 73-86$.

577 38. Bainbridge MN, Wang M, Burgess DL, Kovar C, Rodesch MJ, D’Ascenzo M, Kitzman J, 578 Wu Y-Q, Newsham I, Richmond TA, Jeddeloh JA, Muzny D, Albert TJ, Gibbs RA: Whole 579 exome capture in solution with 3 Gbp of data. Genome Biol 2010, 11:R62.

580 39. McCartney-Melstad, E. Scripts and data used in "Exon Capture Optimization in 581 Large-Genome Amphibians". Zenodo. http://dx.doi.org/10.5281/zenodo.18587. Accessed 582 May 30, 2015. 
bioRxiv preprint doi: https://doi.org/10.1101/021253; this version posted June 19, 2015. The copyright holder for this preprint (which was

not certified by peer review) is the author/funder, who has granted bioRxiv a license to display the preprint in perpetuity. It is made available under aCC-BY-NC-ND 4.0 International license.

Exon capture optimization in a large-genome amphibian

\section{Figures}

Figure 1-Flow chart depicting target enrichment process and key steps affected by experimental variables.

Figure 2-Coverage across a sample target

The black bar on the bottom corresponds to the target region from which probes were synthesized. Each line represents a single library, and each library is shown in a different color. There are two peaks of coverage, one centered on the target region, and a much higher spike of coverage at the left edge of the contig, likely corresponding to a repetitive region in the genome. The latter type of spikes are reduced through the chimera-filtering steps described in the text.

Figure 3-The change in raw mapping rate as a function of post-enrichment qPCR cycle number

Each dot is an individual library: blue $=\mathrm{CTS}$, green $=\mathrm{F} 1$, red $=\mathrm{BTS}^{*}$. Adjusted $\mathrm{R}^{2}=0.1136, \mathrm{p}=$ 0.00784 .

Figure 4-Relationship between post-enrichment DNA concentration and percentage of raw reads mapping to targets

Each dot is an individual library: blue $=\mathrm{CTS}$, green $=\mathrm{F} 1$, red $=\mathrm{BTS} *$. For the full dataset, adjusted $\mathrm{R}^{2}=0.224, \mathrm{p}=0.000204$. After removing the single $\mathrm{F} 1$ outlier, adjusted $\mathrm{R}^{2}=$ $0.1732, \mathrm{p}=0.00126$.

Figure 5-Average sequencing depths across targets

The average sequencing depth across all targets regions averaged between all samples, calculated using samtools depth. The highest 31 values, which had depths higher than 30 , are not shown here.

Figure 6-Relationship between individual input DNA and $c_{0} t-1$ amounts to PCR duplication rates and percentages of unique reads on target

Each dot is an individual library: blue $=\mathrm{CTS}$, green $=\mathrm{F} 1$, red $=\mathrm{BTS} *$. P-values for slope coefficients in the four panels are: top left $\mathrm{p}=1.39 \times 10^{-7}$, top right $\mathrm{p}=9.28 \times 10^{-6}$, bottom left $\mathrm{p}=0.000672$, bottom right $\mathrm{p}=0.00896$.

Figure 7-Predicted vs. actual unique reads on target using two-variable model

The model contains both $\mathrm{c}_{0} \mathrm{t}-1$ and individual input DNA. Points close to the line mean that their unique reads on target are well-predicted by the two variables, and points farther away from the line are not as well predicted. Each dot is an individual library: blue $=\mathrm{CTS}$, green $=\mathrm{F} 1$, red $=\mathrm{BTS}^{*}$. 
bioRxiv preprint doi: https://doi.org/10.1101/021253; this version posted June 19, 2015. The copyright holder for this preprint (which was

not certified by peer review) is the author/funder, who has granted bioRxiv a license to display the preprint in perpetuity. It is made available under aCC-BY-NC-ND 4.0 International license.

Exon capture optimization in a large-genome amphibian

Table 1-Individual libraries (1-53), their treatment levels, and description of yields and sequencing statisttics. Number in parenthesis in library (first column) is the enrichment (124), and shows how libraries were pooled. For example, 22(18) and 25(18) indicates that libraries 22 and 25 were pooled into a single tube (number 18) prior to enrichment.

\begin{tabular}{|c|c|c|c|c|c|c|c|c|}
\hline Library & $\begin{array}{c}\mathrm{X} \\
\mathrm{c}_{0} \mathrm{t} 1 \\
\end{array}$ & $\begin{array}{l}\text { Total DNA in } \\
\text { Capture (ng) }\end{array}$ & $\begin{array}{c}\text { Individual DNA } \\
\text { in Capture (ng) } \\
\end{array}$ & $\begin{array}{l}\text { Sequencing } \\
\text { Yield }(\mathrm{mb})\end{array}$ & $\begin{array}{l}\text { \% Reads } \\
\text { PF } \\
\end{array}$ & \# Reads & $\begin{array}{l}\% \text { Bases } \\
Q>=30\end{array}$ & $\begin{array}{l}\text { Mean Quality } \\
\text { Score } \\
\end{array}$ \\
\hline $1(1)$ & 1 & 500 & 500 & 527 & 98.36 & $3,574,822$ & 88.01 & 34 \\
\hline $2(5)$ & 6 & 500 & 500 & 554 & 98.37 & $3,752,238$ & 89.7 & 34.49 \\
\hline $3(24)$ & 6 & 500 & 40 & 994 & 98.29 & $6,739,256$ & 89.91 & 34.53 \\
\hline $4(4)$ & 6 & 500 & 500 & 399 & 98.43 & $2,702,468$ & 89.57 & 34.45 \\
\hline $5(14)$ & 6 & 1000 & 1000 & 426 & 98.48 & $2,880,694$ & 88.91 & 34.26 \\
\hline $6(24)$ & 6 & 500 & 80 & 2,019 & 98.36 & $13,687,874$ & 90.25 & 34.62 \\
\hline $7(7)$ & 12 & 500 & 500 & 499 & 98.45 & $3,382,090$ & 90.36 & 34.66 \\
\hline $8(11)$ & 1 & 1000 & 1000 & 428 & 98.31 & $2,903,488$ & 88.21 & 34.04 \\
\hline $9(24)$ & 6 & 500 & 100 & 2,096 & 98.36 & $14,207,310$ & 90.18 & 34.6 \\
\hline $10(10)$ & 1 & 1000 & 1000 & 368 & 98.24 & $2,498,034$ & 87.8 & 33.93 \\
\hline $11(17)$ & 12 & 1000 & 1000 & 520 & 98.38 & $3,523,274$ & 90.58 & 34.72 \\
\hline $12(24)$ & 6 & 500 & 120 & 2,507 & 98.31 & $16,999,812$ & 90.05 & 34.57 \\
\hline $13(13)$ & 6 & 1000 & 1000 & 448 & 98.54 & $3,029,216$ & 90.01 & 34.57 \\
\hline $14(3)$ & 6 & 500 & 500 & 408 & 98.54 & $2,757,646$ & 90.86 & 34.8 \\
\hline $15(24)$ & 6 & 500 & 60 & 954 & 98.52 & $6,456,486$ & 90.43 & 34.67 \\
\hline $16(16)$ & 12 & 1000 & 1000 & 409 & 98.58 & $2,764,362$ & 89.99 & 34.56 \\
\hline $17(9)$ & 1 & 1000 & 1000 & 357 & 98.46 & $2,415,210$ & 88.81 & 34.21 \\
\hline $18(2)$ & 1 & 500 & 500 & 404 & 98.46 & $2,738,742$ & 90.57 & 34.72 \\
\hline $19(12)$ & 6 & 1000 & 1000 & 365 & 98.45 & $2,469,008$ & 90.33 & 34.66 \\
\hline $20(8)$ & 12 & 500 & 500 & 472 & 98.58 & $3,190,188$ & 90.61 & 34.74 \\
\hline $21(15)$ & 12 & 1000 & 1000 & 493 & 98.55 & $3,337,582$ & 90.94 & 34.82 \\
\hline $22(18)$ & 1 & 500 & 62.5 & 659 & 98.29 & $4,466,442$ & 88.35 & 34.08 \\
\hline $23(6)$ & 12 & 500 & 500 & 476 & 98.26 & $3,231,866$ & 90.61 & 34.74 \\
\hline $24(19)$ & 6 & 500 & 125 & 937 & 98.51 & $6,343,946$ & 90.46 & 34.68 \\
\hline $25(18)$ & 1 & 500 & 125 & 1,262 & 98.34 & $8,555,454$ & 87.09 & 33.72 \\
\hline $26(19)$ & 6 & 500 & 62.5 & 585 & 98.62 & $3,956,520$ & 89.72 & 34.48 \\
\hline $27(18)$ & 1 & 500 & 62.5 & 527 & 98.46 & $3,571,410$ & 86.5 & 33.57 \\
\hline $28(20)$ & 12 & 500 & 125 & 1,095 & 98.53 & $7,408,314$ & 90.18 & 34.61 \\
\hline $29(19)$ & 6 & 500 & 125 & 1,254 & 98.34 & $8,498,554$ & 89.44 & 34.41 \\
\hline $30(20)$ & 12 & 500 & 62.5 & 481 & 98.37 & $3,256,714$ & 90.11 & 34.6 \\
\hline $31(19)$ & 6 & 500 & 62.5 & 597 & 98.33 & $4,044,512$ & 89.85 & 34.52 \\
\hline $32(18)$ & 1 & 500 & 125 & 869 & 98.42 & $5,886,378$ & 88.81 & 34.21 \\
\hline $33(20)$ & 12 & 500 & 125 & 1,067 & 98.45 & $7,228,628$ & 89.96 & 34.56 \\
\hline $34(19)$ & 6 & 500 & 125 & 1,120 & 98.57 & $7,573,524$ & 89.83 & 34.51 \\
\hline $35(20)$ & 12 & 500 & 62.5 & 440 & 98.56 & $2,976,292$ & 88.85 & 34.25 \\
\hline $36(20)$ & 12 & 500 & 125 & 1,247 & 98.49 & $8,439,750$ & 89.72 & 34.49 \\
\hline $37(18)$ & 1 & 500 & 125 & 777 & 98.49 & $5,262,556$ & 87.91 & 33.96 \\
\hline $38(21)$ & 1 & 1000 & 250 & 1,056 & 98.32 & $7,162,990$ & 88.48 & 34.11 \\
\hline $39(23)$ & 12 & 1000 & 250 & 1,213 & 98.38 & $8,218,358$ & 89.81 & 34.51 \\
\hline $40(22)$ & 6 & 1000 & 250 & 1,222 & 98.46 & $8,271,852$ & 89.66 & 34.47 \\
\hline $41(21)$ & 1 & 1000 & 250 & 1,277 & 98.26 & $8,660,718$ & 88.3 & 34.07 \\
\hline $42(23)$ & 12 & 1000 & 250 & 1,281 & 98.45 & $8,673,266$ & 90.72 & 34.76 \\
\hline $43(21)$ & 1 & 1000 & 125 & 451 & 98.36 & $3,059,160$ & 88.77 & 34.2 \\
\hline $44(21)$ & 1 & 1000 & 250 & 1,273 & 98.3 & $8,633,572$ & 87.49 & 33.84 \\
\hline $45(22)$ & 6 & 1000 & 250 & 1,041 & 98.42 & $7,048,962$ & 89.81 & 34.51 \\
\hline $46(21)$ & 1 & 1000 & 125 & 501 & 98.32 & $3,400,050$ & 88.07 & 34.01 \\
\hline $47(22)$ & 6 & 1000 & 125 & 481 & 98.38 & $3,256,798$ & 89.4 & 34.39 \\
\hline $48(22)$ & 6 & 1000 & 250 & 1,061 & 98.3 & $7,193,568$ & 89.62 & 34.46 \\
\hline $49(23)$ & 12 & 1000 & 250 & 1,228 & 98.39 & $8,319,782$ & 90.38 & 34.67 \\
\hline $50(22)$ & 6 & 1000 & 125 & 636 & 98.62 & $4,296,942$ & 89.56 & 34.44 \\
\hline $51(23)$ & 12 & 1000 & 125 & 483 & 98.61 & $3,263,134$ & 90.42 & 34.68 \\
\hline $52(23)$ & 12 & 1000 & 125 & 568 & 98.28 & $3,851,216$ & 89.59 & 34.46 \\
\hline $53(24)$ & 6 & 500 & 20 & 427 & 98.43 & $2,889,856$ & 90.06 & 34.58 \\
\hline
\end{tabular}


bioRxiv preprint doi: https://doi.org/10.1101/021253; this version posted June 19, 2015. The copyright holder for this preprint (which was not certified by peer review) is the author/funder, who has granted bioRxiv a license to display the preprint in perpetuity. It is made available under aCC-BY-NC-ND 4.0 International license.

Exon capture optimization in a large-genome amphibian

Table 2-Post-enrichment concentrations and sequencing efficiency results. Number in parenthesis in library name as in Table 1.

\begin{tabular}{|c|c|c|c|c|c|c|c|}
\hline Library \# & $\begin{array}{l}\text { Amount of } \\
\text { DNA after post- } \\
\text { enrichment PCR }\end{array}$ & $\begin{array}{l}\text { Average } \\
\text { change in } \\
\text { qPCR } \\
\text { cycle \# }\end{array}$ & $\begin{array}{l}\text { PCR } \\
\text { duplication } \\
\text { rate }\end{array}$ & $\begin{array}{l}\text { Raw } \\
\text { mapping } \\
\text { rate }\end{array}$ & $\begin{array}{l}\text { Unique } \\
\text { read } \\
\text { mapping } \\
\text { rate }\end{array}$ & $\begin{array}{l}\text { Average } \\
\text { depth } \\
\text { across } \\
\text { target }\end{array}$ & $\begin{array}{c}\text { Highest } \\
\text { 100bp } \\
\text { window } \\
\text { ave. depth }\end{array}$ \\
\hline $1(1)$ & 74.1746508 & 9.2388 & $22.24 \%$ & $15.19 \%$ & $11.81 \%$ & 6.27 & 7.68 \\
\hline $2(5)$ & 47.82866 & 8.113 & $16.70 \%$ & $32.89 \%$ & $27.40 \%$ & 18.63 & 21.76 \\
\hline $3(24)$ & 350.64 & 9.864 & $30.26 \%$ & $16.72 \%$ & $11.66 \%$ & 6.58 & 7.74 \\
\hline $4(4)$ & 32.15888 & 7.6988 & $16.21 \%$ & $25.41 \%$ & $21.29 \%$ & 13.22 & 15.85 \\
\hline $5(14)$ & 99.542055 & 10.883 & $11.39 \%$ & $34.79 \%$ & $30.83 \%$ & 20.89 & 24.45 \\
\hline $6(24)$ & 350.64 & 9.864 & $33.19 \%$ & $16.63 \%$ & $11.11 \%$ & 6.32 & 7.31 \\
\hline $7(7)$ & 347.135 & 8.505 & $10.58 \%$ & $16.28 \%$ & $14.55 \%$ & 7.70 & 9.27 \\
\hline $8(11)$ & 216.706105 & 8.632 & $15.23 \%$ & $16.00 \%$ & $13.56 \%$ & 7.74 & 9.42 \\
\hline $9(24)$ & 350.64 & 9.864 & $33.57 \%$ & $15.93 \%$ & $10.59 \%$ & 5.94 & 6.86 \\
\hline $10(10)$ & 165.65566 & 9.1638 & $16.33 \%$ & $16.45 \%$ & $13.76 \%$ & 7.54 & 9.31 \\
\hline $11(17)$ & 379.095 & 9.446 & $9.21 \%$ & $15.84 \%$ & $14.38 \%$ & 7.78 & 9.30 \\
\hline $12(24)$ & 350.64 & 9.864 & $33.72 \%$ & $16.14 \%$ & $10.69 \%$ & 5.99 & 6.88 \\
\hline $13(13)$ & 74.65109 & 8.863 & $11.91 \%$ & $25.69 \%$ & $22.63 \%$ & 13.97 & 16.59 \\
\hline $14(3)$ & 81.971965 & 7.82 & $11.59 \%$ & $17.08 \%$ & $15.10 \%$ & 8.73 & 10.62 \\
\hline $15(24)$ & 350.64 & 9.864 & $29.10 \%$ & $18.83 \%$ & $13.35 \%$ & 7.86 & 9.20 \\
\hline $16(16)$ & 439.73 & 8.461 & $9.11 \%$ & $16.27 \%$ & $14.79 \%$ & 7.68 & 9.32 \\
\hline $17(9)$ & 172.37966 & 10.187 & $14.21 \%$ & $16.92 \%$ & $14.52 \%$ & 8.65 & 10.60 \\
\hline $18(2)$ & 2150.07215 & 4.652 & $19.62 \%$ & $6.74 \%$ & $5.42 \%$ & 0.27 & 0.47 \\
\hline $19(12)$ & 161.068535 & 10.435 & $8.73 \%$ & $21.05 \%$ & $19.22 \%$ & 11.91 & 14.30 \\
\hline $20(8)$ & 250.64 & 9.833 & $8.84 \%$ & $16.96 \%$ & $15.46 \%$ & 8.52 & 10.19 \\
\hline $21(15)$ & 269.695 & 9.999 & $8.51 \%$ & $16.34 \%$ & $14.95 \%$ & 8.43 & 10.09 \\
\hline $22(18)$ & 57.148215 & 6.668 & $47.05 \%$ & $16.72 \%$ & $8.86 \%$ & 4.69 & 5.72 \\
\hline $23(6)$ & 439.78 & 9.773 & $8.75 \%$ & $15.76 \%$ & $14.38 \%$ & 8.16 & 9.80 \\
\hline $24(19)$ & 117.984425 & 9.637 & $31.86 \%$ & $13.54 \%$ & $9.22 \%$ & 4.45 & 5.36 \\
\hline $25(18)$ & 57.148215 & 6.668 & $48.59 \%$ & $17.62 \%$ & $9.06 \%$ & 4.74 & 5.64 \\
\hline $26(19)$ & 117.984425 & 9.637 & $30.90 \%$ & $15.41 \%$ & $10.65 \%$ & 5.46 & 6.63 \\
\hline $27(18)$ & 57.148215 & 6.668 & $47.69 \%$ & $17.59 \%$ & $9.20 \%$ & 4.66 & 5.76 \\
\hline $28(20)$ & 93.68 & 10.432 & $19.83 \%$ & $18.28 \%$ & $14.65 \%$ & 8.37 & 9.72 \\
\hline $29(19)$ & 117.984425 & 9.637 & $33.69 \%$ & $16.59 \%$ & $11.00 \%$ & 5.67 & 6.70 \\
\hline $30(20)$ & 93.68 & 10.432 & $17.64 \%$ & $19.97 \%$ & $16.44 \%$ & 9.67 & 11.49 \\
\hline $31(19)$ & 117.984425 & 9.637 & $31.14 \%$ & $15.79 \%$ & $10.87 \%$ & 5.39 & 6.55 \\
\hline $32(18)$ & 57.148215 & 6.668 & $46.67 \%$ & $17.01 \%$ & $9.07 \%$ & 5.08 & 6.15 \\
\hline $33(20)$ & 93.68 & 10.432 & $21.03 \%$ & $19.26 \%$ & $15.21 \%$ & 8.55 & 9.96 \\
\hline $34(19)$ & 117.984425 & 9.637 & $32.57 \%$ & $14.22 \%$ & $9.59 \%$ & 4.96 & 5.90 \\
\hline $35(20)$ & 93.68 & 10.432 & $16.78 \%$ & $20.18 \%$ & $16.79 \%$ & 9.60 & 11.49 \\
\hline $36(20)$ & 93.68 & 10.432 & $20.87 \%$ & $18.46 \%$ & $14.61 \%$ & 8.67 & 10.05 \\
\hline $37(18)$ & 57.148215 & 6.668 & $46.14 \%$ & $16.53 \%$ & $8.90 \%$ & 4.82 & 5.83 \\
\hline $38(21)$ & 252.28847 & 9.128 & $28.10 \%$ & $15.24 \%$ & $10.96 \%$ & 6.09 & 7.24 \\
\hline $39(23)$ & 364.13 & 7.482 & $17.49 \%$ & $17.00 \%$ & $14.03 \%$ & 7.64 & 8.91 \\
\hline $40(22)$ & 70.102805 & 10.725 & $38.12 \%$ & $25.89 \%$ & $16.02 \%$ & 10.11 & 11.74 \\
\hline $41(21)$ & 252.28847 & 9.128 & $29.75 \%$ & $15.74 \%$ & $11.05 \%$ & 6.03 & 7.10 \\
\hline $42(23)$ & 364.13 & 7.482 & $16.69 \%$ & $17.99 \%$ & $14.98 \%$ & 8.82 & 10.22 \\
\hline $43(21)$ & 252.28847 & 9.128 & $25.29 \%$ & $15.92 \%$ & $11.89 \%$ & 6.36 & 7.78 \\
\hline $44(21)$ & 252.28847 & 9.128 & $30.89 \%$ & $16.01 \%$ & $11.06 \%$ & 5.75 & 6.81 \\
\hline $45(22)$ & 70.102805 & 10.725 & $35.17 \%$ & $26.01 \%$ & $16.86 \%$ & 10.52 & 12.25 \\
\hline $46(21)$ & 252.28847 & 9.128 & $27.01 \%$ & $16.25 \%$ & $11.86 \%$ & 6.15 & 7.53 \\
\hline $47(22)$ & 70.102805 & 10.725 & $34.28 \%$ & $24.80 \%$ & $16.30 \%$ & 10.11 & 12.06 \\
\hline $48(22)$ & 70.102805 & 10.725 & $37.39 \%$ & $24.78 \%$ & $15.52 \%$ & 9.33 & 10.92 \\
\hline $49(23)$ & 364.13 & 7.482 & $16.22 \%$ & $17.79 \%$ & $14.90 \%$ & 8.48 & 9.81 \\
\hline $50(22)$ & 70.102805 & 10.725 & $36.08 \%$ & $26.28 \%$ & $16.80 \%$ & 10.22 & 12.10 \\
\hline $51(23)$ & 364.13 & 7.482 & $11.98 \%$ & $18.77 \%$ & $16.52 \%$ & 9.45 & 11.23 \\
\hline $52(23)$ & 364.13 & 7.482 & $14.06 \%$ & $17.15 \%$ & $14.74 \%$ & 7.83 & 9.35 \\
\hline $53(24)$ & 350.64 & 9.864 & $26.20 \%$ & $17.21 \%$ & $12.70 \%$ & 6.98 & 8.46 \\
\hline
\end{tabular}


Exon capture optimization in a large-genome amphibian

Table 3-Model comparison predicting percentage of unique reads on target, sorted by AIC values

$* * *$ signifies $\mathrm{p}<0.001, * *$ signifies $0.001<\mathrm{p}<0.01, *$ signifies $0.01<\mathrm{p}<0.05$.

\begin{tabular}{|l|c|c|c|}
\hline \multicolumn{1}{|c|}{ Model } & $\mathbf{R}^{\mathbf{2}}$ & Adj. $\mathbf{R}^{\mathbf{2}}$ & AIC \\
\hline $\mathrm{c}_{0} \mathrm{t}{ }^{* *}+$ inputDNA $^{* * *}$ & 0.3252 & 0.2982 & -193.6057 \\
\hline inputDNA $^{* * *}$ & 0.2046 & 0.189 & -186.8963 \\
\hline $\mathrm{c}_{0} \mathrm{t}-1^{* *}$ & 0.1265 & 0.1094 & -181.9297 \\
\hline
\end{tabular}

Table 4-Model comparison predicting average depth across target region, sorted by AIC values

$* * *$ signifies $\mathrm{p}<0.001, * *$ signifies $0.001<\mathrm{p}<0.01, *$ signifies $0.01<\mathrm{p}<0.05$.

\begin{tabular}{|l|c|c|c|}
\hline \multicolumn{1}{|c|}{ Model } & $\mathbf{R}^{\mathbf{2}}$ & Adj. $\mathbf{R}^{\mathbf{2}}$ & AIC \\
\hline $\mathrm{c}_{0} \mathrm{t}{ }^{*}+$ inputDNA $^{* *}$ & 0.252 & 0.222 & 269.6817 \\
\hline inputDNA $^{* *}$ & 0.1676 & 0.1513 & 273.3437 \\
\hline $\mathrm{c}_{0} \mathrm{t}-1^{*}$ & 0.08887 & 0.07101 & 278.1344 \\
\hline
\end{tabular}


Extract DNA

\section{Prepare}

libraries

Future directions: Increase amount of sample DNA going into library preparation

Variable \#1: Modifying the amount of DNAs for

Enrichment sample DNA going into enrichment

$\downarrow$

Add blockers ( $\mathrm{c}_{0} \mathrm{t}-1$, adapter blockers, etc...)

Variable \#2: Increasing the amount of $\mathrm{c}_{0} \mathrm{t}-1$ going into enrichment

Add capture probes and hybridize $\downarrow$

Wash, amplify, and sequence 


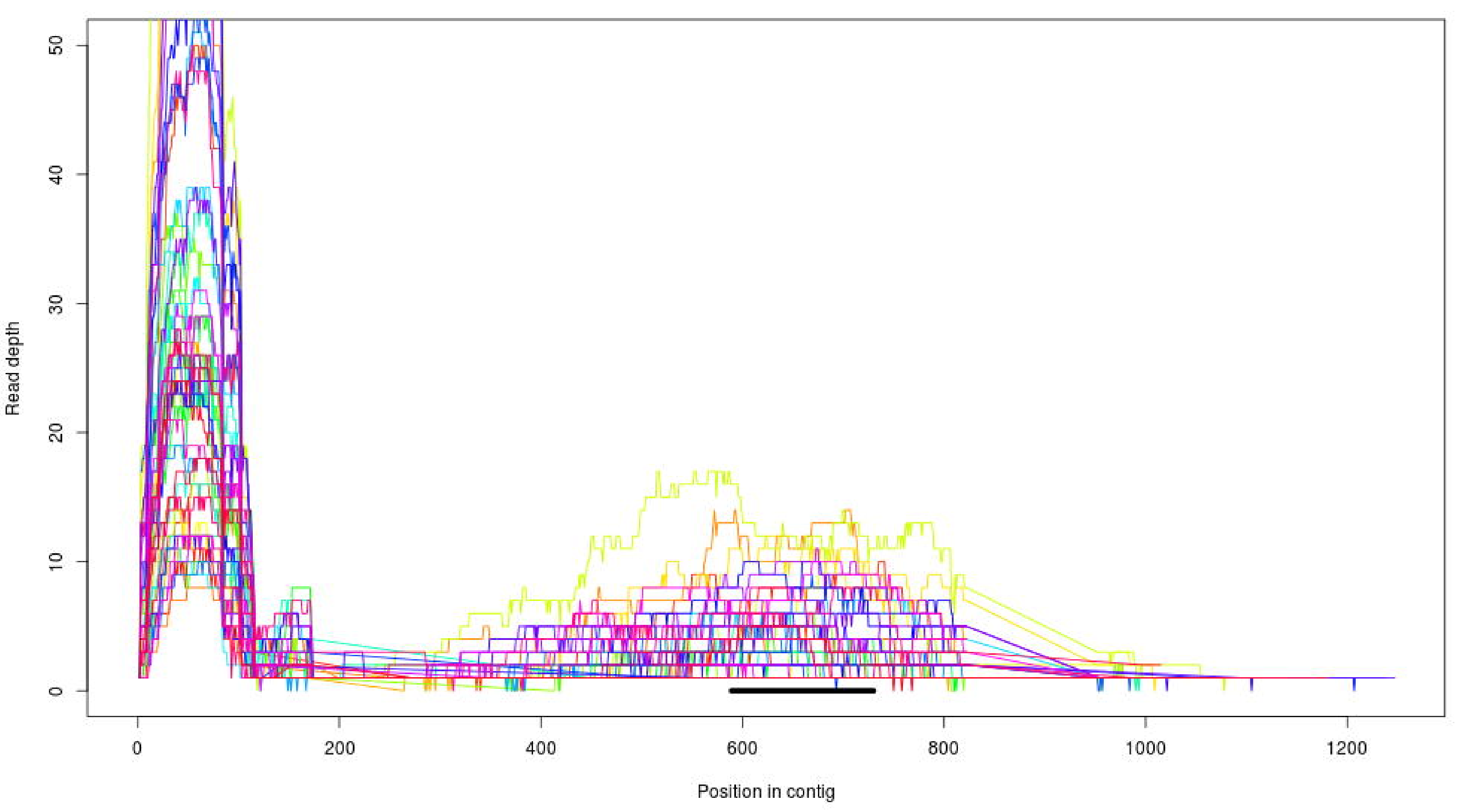




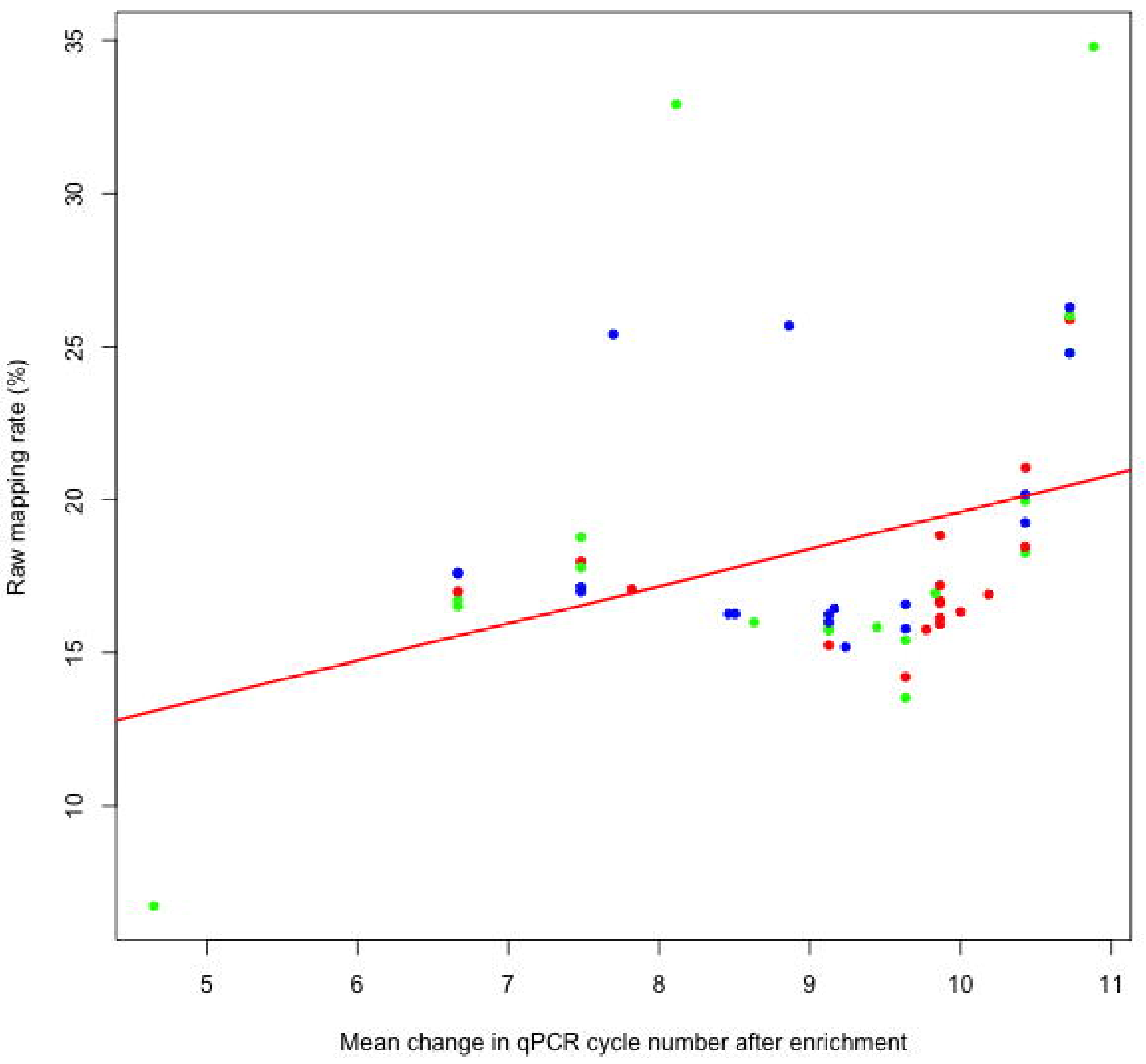




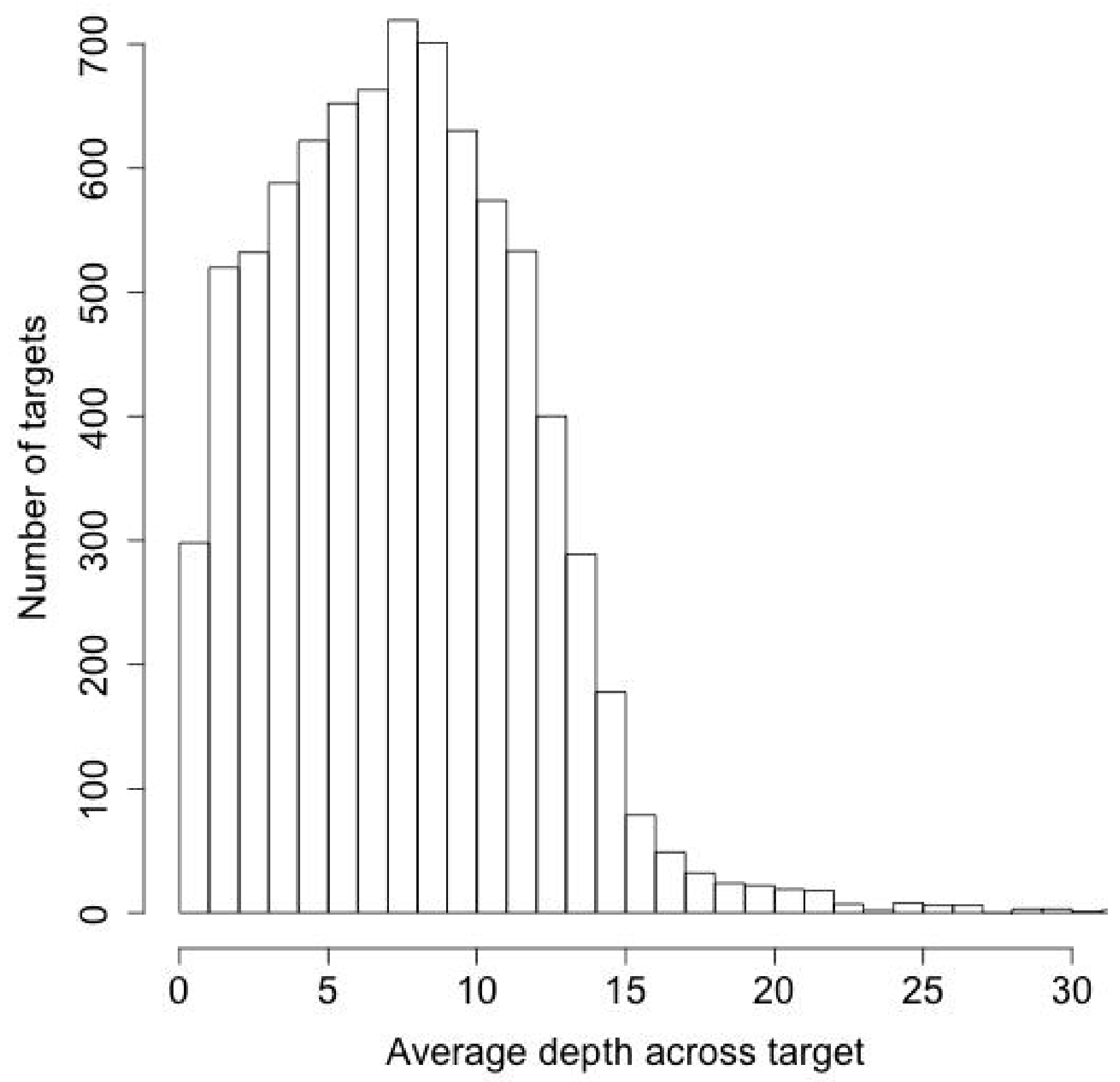


Input DNA vs. PCR duplication rate

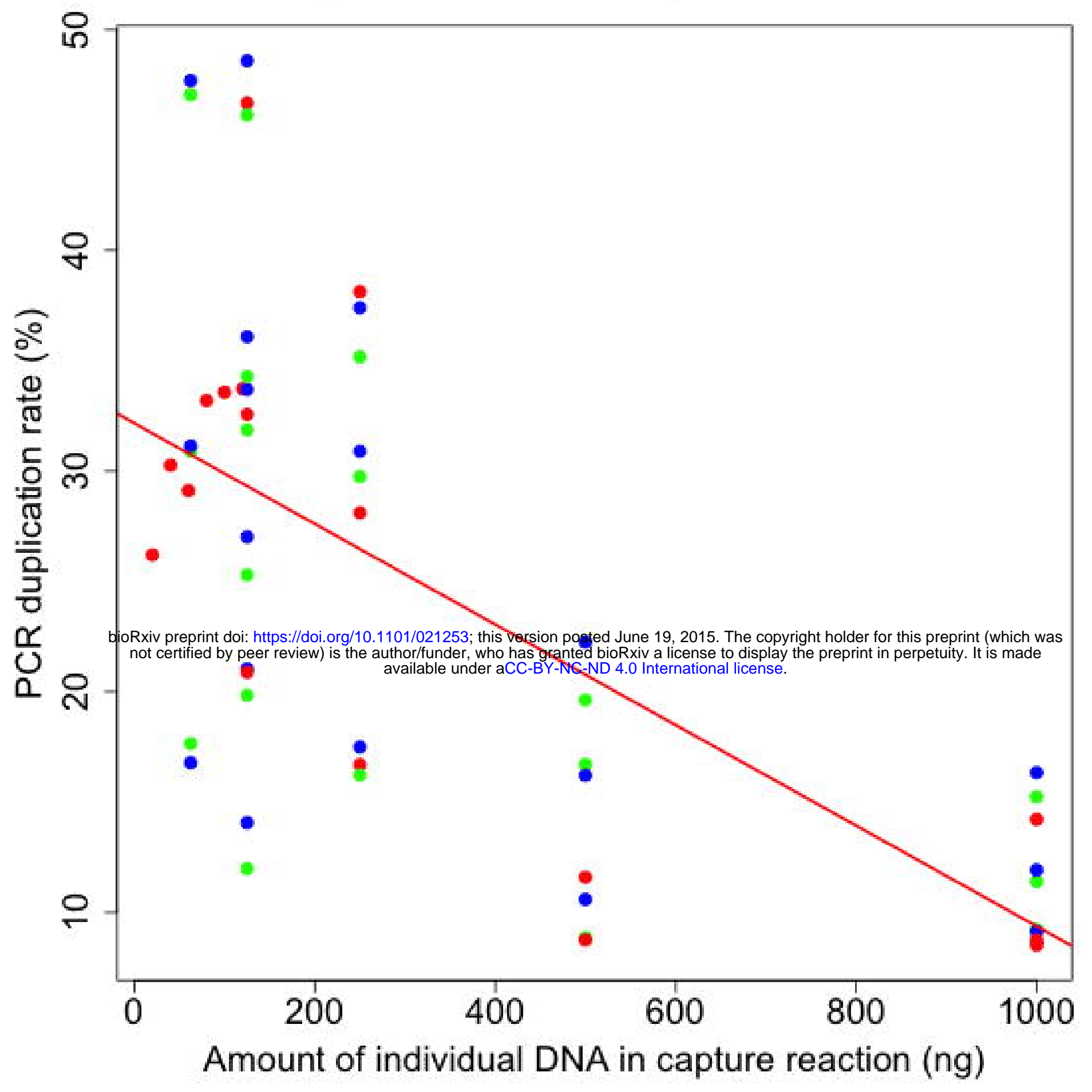

Input DNA vs. unique reads on target

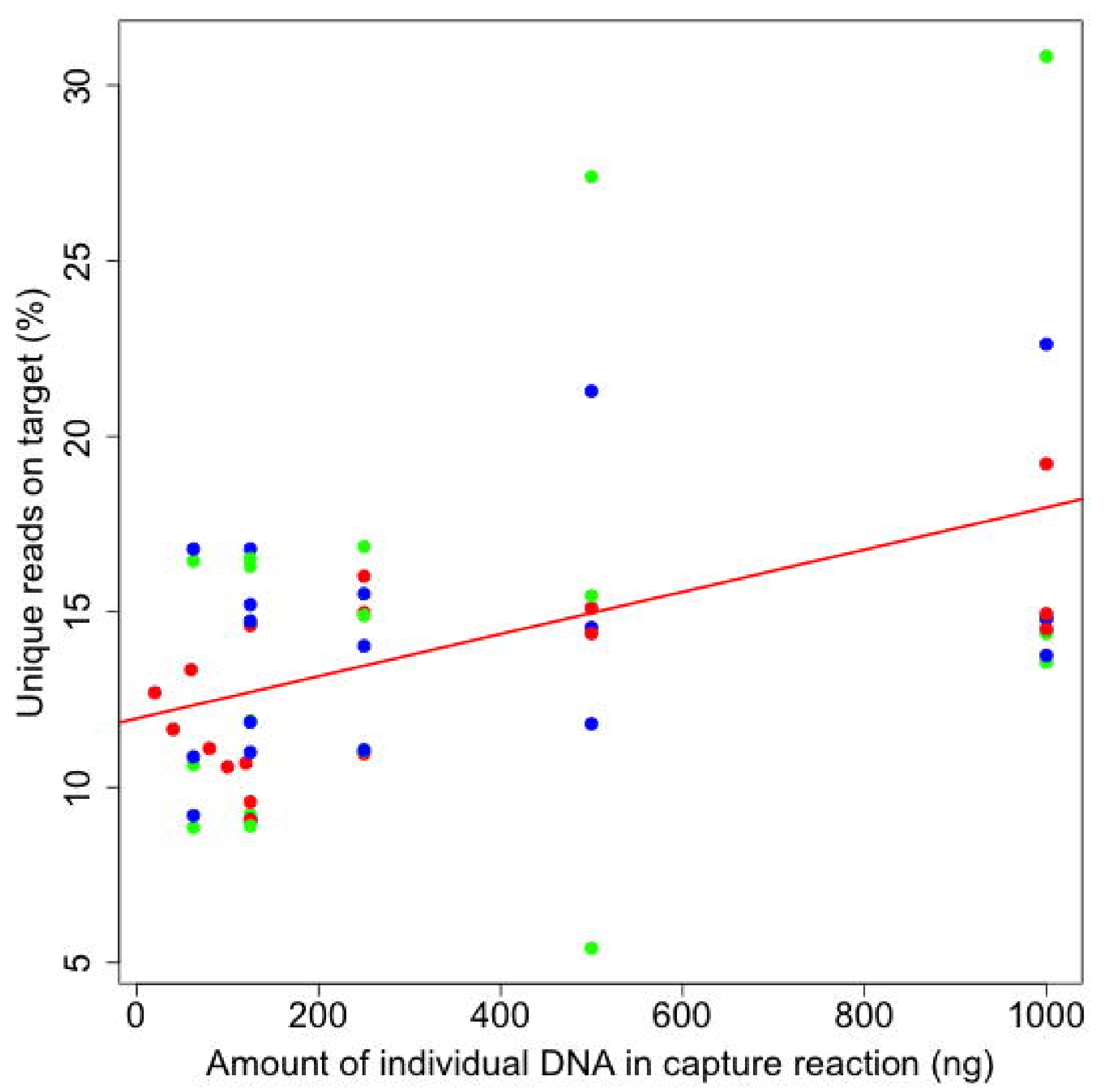

Amount of c0t-1 vs. PCR duplication rate

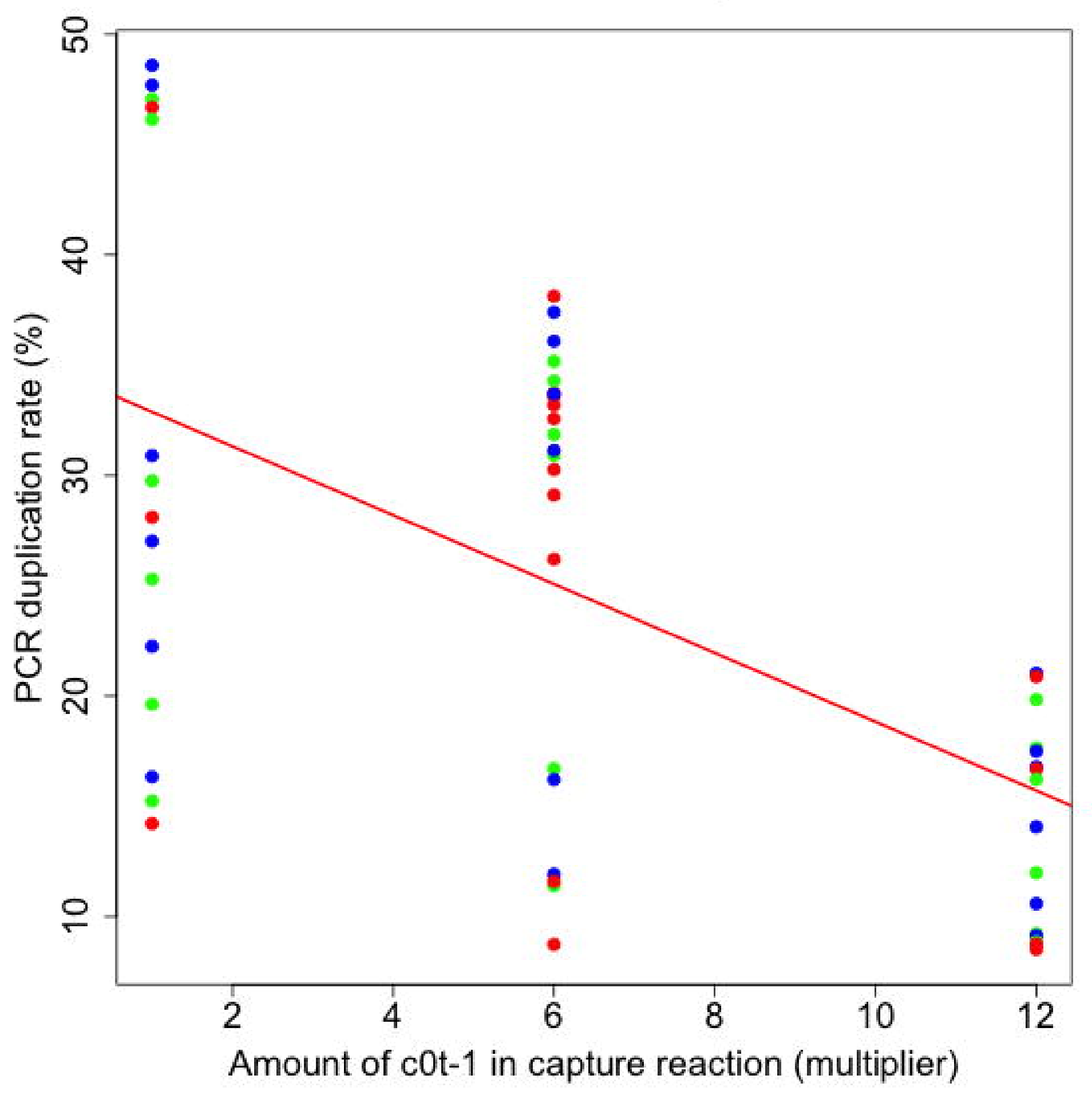

Amount of c0t-1 vs. unique reads on target

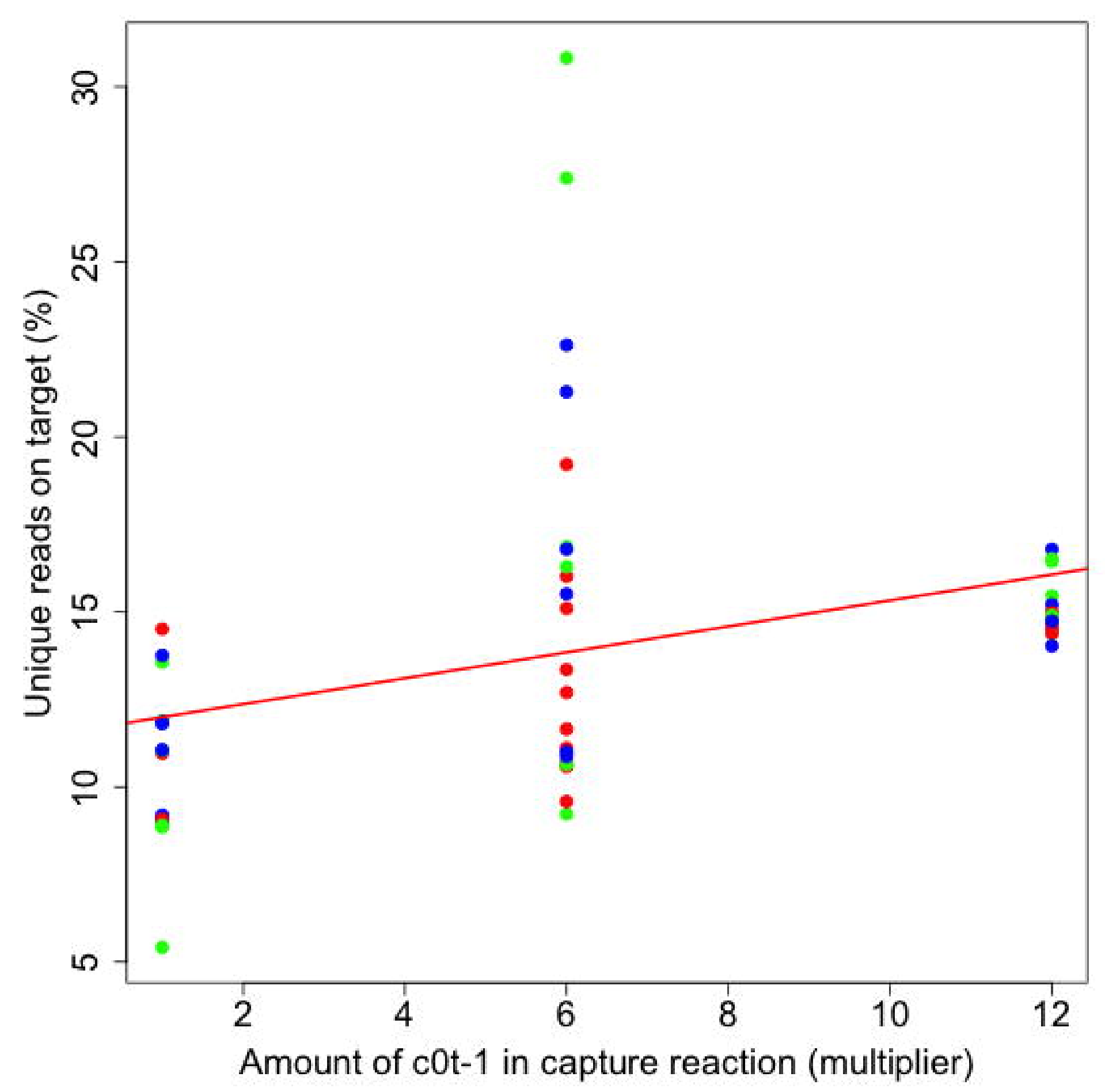




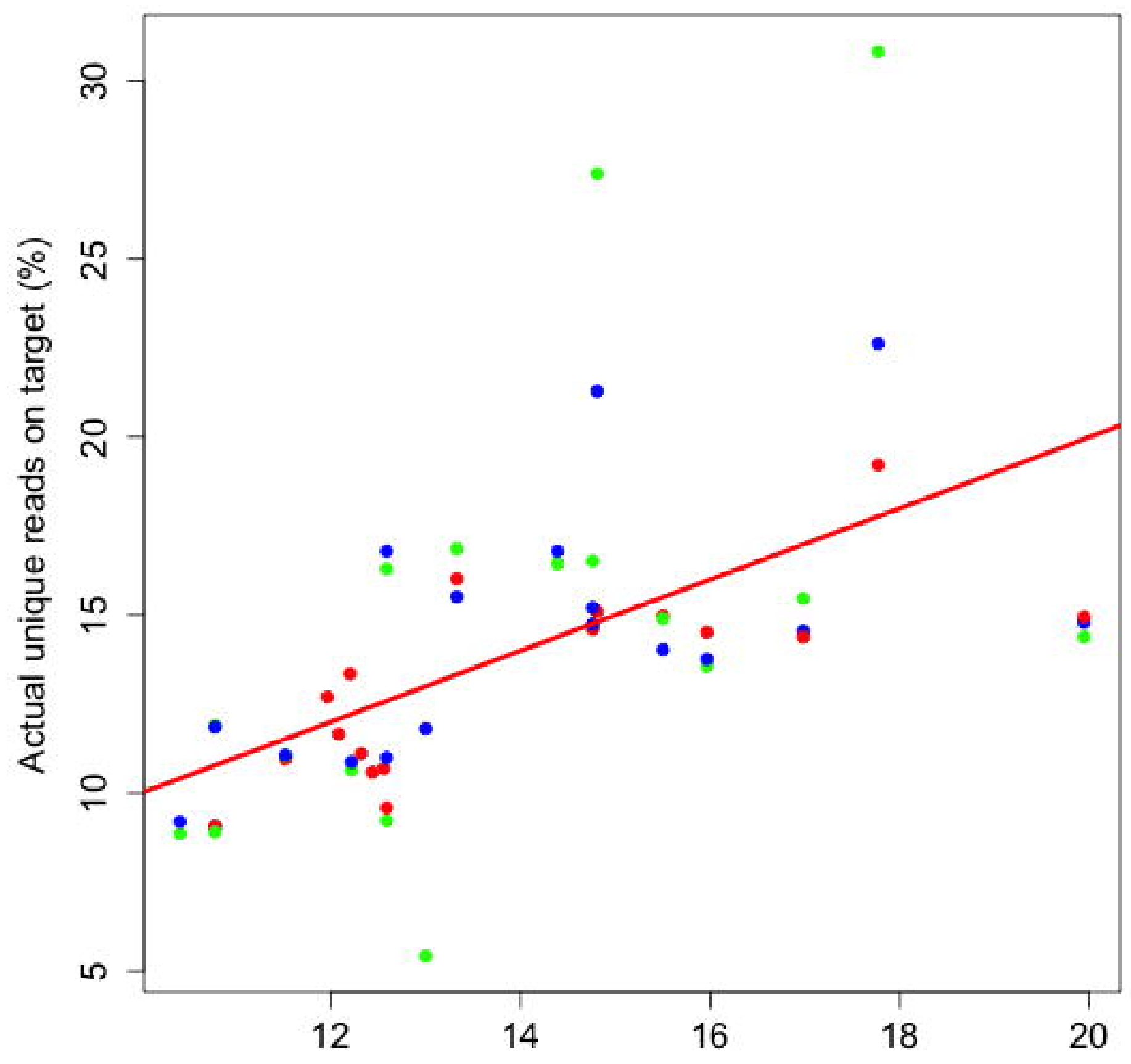

Predicted unique reads on target from c0t-1 + individual input DNA model (\%) 